\title{
Az oktatási rendszer kulcsszereplői: pedagógusok Kárpátalján az ukrán válság éveiben
}

\author{
FERENC VIKTÓRIA ${ }^{1}$
}

\begin{abstract}
ABSZTRAKT
2017 tavaszán 338 kárpátaljai gyakorló pedagógus között végeztünk felmérést anyagi és szakmai elégedettségükröl, illetve a migrációval kapcsolatos terveikről. A kutatási eredmények rámutattak, hogy az egyik legsúlyosabb probléma az alacsony keresetekkel van összefüggésben. A migrációt fontolgatók leginkább az anyagi elégedetlenség miatt hagynák el az országot, ezt követően a családi, párkapcsolati okok a mérvadók. Szakmai kiégésről azonban nem beszélhetünk a pedagógusok között. A megkérdezettek 72\%-a, bár elégedetlen helyzetével, nem gondolkodik a kitelepedésen, vagy elutasítja ennek a gondolatát is. A veszélyeztetettebb kategóriát az a 84 fö jelenti (25\%), akinek már vannak elképzelései a kitelepedéssel kapcsolatban, illetve az az 5 fó (2\%) aki már konkrét lépéseket is tett. Ebben a két kategóriában föleg a fiatalabb pedagógusok képviseltetik magukat. A legfontosabb célországnak Magyarország számít. A maradók és a menni szándékozók között is magas a magyar állampolgársággal rendelkezők aránya, ezért ezt nem tekinthetjük a kivándorlás egyértelmú katalizátorának a pedagógusok között.
\end{abstract}

KULCSSZAVAK: pedagógusok, válság, szakmai és anyagi elégedettség, elvándorlás

\section{ABSTRACT}

Key players of the education system:

teachers in Transcarpathia in the years of the Ukrainian crisis

In spring 2017 a survey was carried out among 338 practicing Transcarpathian Hungarian teachers about their material and professional satisfaction and migration plans. The study highlighted that one of the most crucial problems of the teachers is the low salary. Among those who are contemplating migration the main push factor is material dissatisfaction, followed by family and partnership reasons. However, we cannot speak about professional burn-out in their case. $72 \%$ of the respondents, without being satisfied with their situation, still does not think about migration, or is pretty sure about staying at the homeland. 84 persons (25\%) belong to an endangered group, in which people embrace the idea of migration. Only 5 persons have done concrete steps in this direction. In these two groups we find mainly youger teachers. The

\footnotetext{
${ }^{1}$ Nemzetpolitikai Kutatóintézet, kutató, PhD.
} 
www. metszetek.unideb.hu

\section{TEMATIKUS TANULMÁNYOK - Kárpátalja társadalma}

most important destination country is Hungary. Among the respondents there is high number of Hungarian citizenship holders, however it is not an obvious catalyst of migration: people who are willing to go or willing to stay cannot be differentiated according to this aspect.

KEYWORDS: teachers, crisis, professional and material satisfaction, migration

\section{Bevezetés - A pedagógus mint kulcsszereplő}

A kisebbségi közösségek megmaradása, az identitás megtartása és átörökítése szempontjából az oktatási rendszer működésének jellemzői mindig meghatározóak. A kisebbségi oktatási struktúrát több szempontból vizsgálhatjuk, amire Kárpátalja tekintetében az utóbbi években számos kutatás tett kísérletet. E kutatások közül jó néhány rámutatott, hogy a pedagógusokat méltán nevezhetjük az oktatási rendszer kulcsszereplőinek.

A kisebbségi magyar szülők iskolaválasztási motivációinak feltárása során, amelyek az etnikailag semleges, praktikus érvek és az etnikailag meghatározott, kifejezetten a kisebbségi létből fakadó motivációk beazonosítására törekedtek, kiderült, hogy az etnikailag semleges motivációk közül a pedagógus személye fontos vonzóerőt jelent a szülők számára, különösen a beiskolázás alsóbb szintjein (óvoda, kisiskola) (Ferenc - Séra 2012: 489). Tudjuk, hogy a szülők egy része a pedagógusok munkához való hozzáállása alapján ítéli meg az iskola színvonalát, s választja ki a számára megfelelő intézményt (Ferenc 2013: 105). Egy másik Kárpátalján végzett kutatásból arra is fény derült, hogy nem feltétlenül azok a diákok teljesítenek jobban, akik jobb családi háttérrel rendelkeznek: vagyis az egyes intézményekben folyó pedagógiai munka bizonyos esetekben a családi háttérből megjósolható eredményeket kihasználatlanul hagyja, máskor viszont képes a gyerek családi hátteréből fakadó rosszabb esélyeit javítani (Ferenc 2014, Papp 2013). A pedagógus személye és a munkája során létrehozott pedagógiai hozzáadott érték úgy tűnik, kulcsfontosságú az oktatási rendszer hatékony működése szempontjából. Ebből kifolyólag a kutatókat nem véletlenül foglalkoztatja, hogy milyen alapvető tulajdonságokkal rendelkezik a jó tanár (Korthagen 2004). A támogató személyiségjegyek mellett ugyanakkor számos olyan környezeti tényező is létezik, ami a tanárok teljesítményét jó vagy rossz irányban billentheti. A pedagógus szakmát világszinten jellemző nehézségek - a hallgatók körében a bizonytalan pályára állás, a gyakorló pedagógusok között a kiégés, pályaelhagyás - mellett az ukrán válság következményeként Kárpátalján jelenleg érezhető gazdasági, politikai viszonyok miatt a magyar pedagógusok helyzete az átlagosnál nehezebbé vált. 


\section{TEMATIKUS TANULMÁNYOK - Kárpátalja társadalma}

\section{A kutatás módszertana}

A Kárpátaljai Magyar Pedagógus Szövetség, a Lehoczky Tivadar Társadalomtudományi Kutatóközpont és a Nemzetpolitikai Kutatóintézet együttmúködésével 2017 tavaszán kérdőíves vizsgálattal a kárpátaljai magyar tannyelvű intézmények pedagógusainak szakmai és anyagi elégedettségét, biztonságérzetét, a szülőföldön maradásra vagy annak elhagyására vonatkozó terveit próbáltuk meg feltárni. ${ }^{2}$ A pedagógusokat a Kárpátaljai Magyar Pedagógus Szövetség adatbázisán alapuló 400 fős reprezentatív minta kiválasztása után kerestük meg, amely a megye teljesen, illetve részben magyar tannyelvű iskoláiban és óvodáiban 2016/17-ben tanító pedagógusokra vonatkozott. A minta kiválasztása közben figyelemmel voltunk a teljes pedagógustársadalom eloszlásának települési sajátosságaira (falu vagy város), az oktatási intézménytípusokra (óvodák, elemi, általános és középiskolák), a nemek megoszlására, valamint az életkorra. ${ }^{3}$ A kérdőív névtelen és önkéntes volt. Az önkéntességre hivatkozva, a kérdések érzékenysége miatt a mintába beválogatott pedagógusok egy része visszautasította a kutatásban való részvételt. Az így megüresedett helyeket igyekeztünk más pedagógusokkal pótolni, de még így is kevesebb kérdőívet sikerült gyüjtenünk, mint amennyit terveztünk.

Összesen 338 gyakorló pedagógussal sikerült a kérdőívet kitöltenünk. A kitöltött kérdőíveket SPSS program segítségével rögzítettük, az így létrejövő adtabázist pedig azzal a fó céllal elemeztük, hogy ismereteket nyerjünk a pedagógusok migrációs terveiről, valamint ezen tervek háttértényezőiről, úgy mint a szakmai és anyagi elégedettség, a családi helyzet, a kor, a nyelvtudás, a magyar állampolgársággal való rendelkezés, vagy a tágabban értelmezett társadalmi-politikai környezet. A viszonylag alacsony elemszámra való tekintettel az egyes tényezők egymásra való hatásának vizsgálatakor a szignifikáns eltérést jelző Khí-négyzet próba értékét az általános 0,001-ről 0,005-re emeljük elemzésünkben.

\section{Elméleti háttér}

Az Ukrajnában kialakult gazdasági és politikai válság szinte természetes módon hozta magával a kifelé irányuló migráció növekedését, egyrészt a katonai behívók előli meneküléssel összefüggésben (ami főleg katonaköteles férfiakat érint), másrészt a kilátástalan gazdasági körülmények miatt. A kárpátaljai magyar pedagógusok többségében nők, ezért a behívók előli menekülés csak egy szűk réteget érint, de a gazdasági ellehetetlenülés esetükben is reális kockázatot jelent a migrációra, illetve

\footnotetext{
${ }^{2}$ A kutatás támogatója a Nemzetpolitikai Államtitkárság megbízásából a Bethlen Gábor Alap volt.

${ }^{3}$ A kutatás alapjául szolgáló mintavételt Molnár József készítette. A kérdőívezés helyi koordinációjában Darcsi Karolina vállalt oroszlánrészt.
} 


\section{TEMATIKUS TANULMÁNYOK - Kárpátalja társadalma}

a családtagjaik kényszerú migrációja miatt maguk is érintettekké válhatnak (pl. követik férjüket, gyereküket).

Egy 2014-ben készült nemzetközi kutatás a pedagógus migráció egyre növekvő trendjével foglalkozott, amelynek számos különböző típusa és motivációja létezik a szakmai továbblépés példaértékű formájától az anyagi kizsákmányoláson át (Caravatti et al. 2014: 4). A kutatás 1358 kérdőív alapján arra jut, hogy a nő nemű pedagógusok számára a szakmai fejlődés jelenti az elsődleges motivációt a migrációra, a férfiak körében viszont a jobb megélhetés a legfontosabb. Nyitott kérdésekből az is kiderül, hogy a tanárok saját (vallási, szexuális) szabadságukat is keresik amikor elhagyják a kibocsájtó országot, és az is jellemző, hogy belefáradnak az otthoni oktatási rendszer nehézkes müködésébe. A családi okok is fontosnak tûntek a nemzetközi szinten: az adatközlők nagy része már kint lévő családtagot követett a kivándorláskor, illetve a fontosabb motivációk között említették, hogy gyermekeiknek jobb körülményeket tudnak a migráció által biztosítani. A befogadó országban őket ért főbb kihívások során is az első helyen jelenik meg a család kérdése: a családtól való elszigeteltség a legnagyobb nehézség, amellyel a befogadó országban szembesülnek (Caravatti et al. 2014: 31-32).

Azt látjuk tehát, hogy a stabil családi helyzet, a gyermekek megléte egyrészről a migráció ellen ható erő, hiszen családdal együtt mozogni sokkal nagyobb kockázatot jelent; gondoskodni kell a lakhatásról, munkahelyekről, a gyermekek iskoláztatásáról. Ugyanakkor a már külföldön lévő családtagoktól való elszigeteltség érzése jelenthet komoly toló tényezőt is a migrációra, a már kitelepült rokonság, az előőrsök és a korábbi utazási tapasztalatok az első lépések megtételében sokat segíthetnek (Grassi - Ferreira 2016).

E globális migrációs trendek hatása a pedagógusokra valahol természetesnek is vehető, ezzel párhuzamosan pedig világszerte a pedagógusi pálya elnőiesedése is tetten érhető (Menter 2010). Ennek egyik okaként azt a tradicionális világszemléletben gyökerező érvet szokták említeni, miszerint a pedagógusi szakma tulajdonképpen ún. félprofesszióvá vált az idők során, hiszen anyagi megbecsültsége túl alacsony ahhoz, hogy a családfenntartó férfi számára is vonzó maradhasson, a gyermekneveléssel viszont sok nő jól összeegyeztethetőnek tartja. Különösen igaz ez a megállapítás az oktatás alsó szintjeire (óvoda és elemi iskola), ahol egyenesen „,szokatlan”, „különc” és „deviáns” jelenségként tekintenek a férfiak jelenlétére (Carrington 2002).

A migráció vizsgálatakor a nyelvtudás kérdésére is kitérünk. Már korábbi kutatások ${ }^{4}$ is kimutatták, hogy a kárpátaljai magyarok államnyelvtudása Kárpát-medencei összehasonlításban alacsonynak számít. A jelenség hátterében található okok beazonosítására is történtek kísérletek: a leginkább a rossz módszertani alapokon

${ }^{4}$ A magyar nyelv a Kárpát-medencében a XX. század végén (1996), vagy a Kárpát Panel (2007) c. kutatási programok eredményeit (lásd pl. Csernicskó 2009a, Papp - Veres 2007). 


\section{TEMATIKUS TANULMÁNYOK - Kárpátalja társadalma}

nyugvó, nem elég hatékony iskolai államnyelvoktatás, és a magyarlakta tömb elszigeteltsége a legfőbb akadályozója az államnyelv magasabb szintű elsajátításának (Csernicskó 2009b). A alacsony államnyelvtudása a szakmai előmenetel során is komoly problémát okozhat, hiszen a pedagógus továbbképzések a többségi pedagógusokkal közösen szerveződnek, az előadások, foglalkozások nyelve legtöbb esetben az államnyelv. A munkahelyen az iskolai adminisztráció nyelve szintén az ukrán. Ha a pedagógusi kategóriájuk megerősítésére, vagy új kategória megszerzésére kerül a sor, a nyíltórák megtartása, amelyen külső értékelők is részt vesznek, ugyan történhet a tannyelv szerinti nyelven, de a kiértékelés, a szakmai megbeszélés már államnyelven folyik. Vagyis a nyelvtudás (hiánya) akadályozhatja a szakmai-társadalmi integrációt, ami szintén jelenthet toló tényezőt a elvándorláskor.

Tátrai és kutatótársai szerint Kárpátalján a magyar állampolgárság megszerzése az egyik legfontosabb egyéni/családi (migrációs) stratégia a gazdasági ellehetetlenülés és a besorozások elkerülésére, és a magyar útlevél egyben a kivándorlás katalizátora is (Tátrai et al 2016: 89). Kérdőívünkkel mi is megvizsgáltuk, hogy e speciális csoportban, hogyan alakul az állampolgársággal rendelkezés és a migrációs szándék összefüggése.

2016 közepére - a migráció következtében - jelentős tanárhiány alakult ki a kárpátaljai magyar iskolákban. ${ }^{5}$ Már egy korábbi, 2015-ös pedagógus-hallgatókat vizsgáló kutatás is rámutatott, hogy különösen a fiatalabb, pályakezdés előtt álló pedagógusok vannak a migrációs nyomásnak kitéve: bár a pedagógusjelöltek 75\%-a a képesítés megszerzése után szeretne pedagógusként elhelyezkedni, de az elhelyezkedés földrajzi dimenzióit tekintve a mintának csak 43\%-a maradna a szülőföldjén, 39\% már a külföldre (főleg Magyarországra) költözés gondolatát fontolgatja. Mindez azonban egy lappangó, még visszafordítható jelenségként testesül meg, és a dilemmát jól érzékelteti, hogy $15 \%$ az olyan válaszok aránya, ahol mindkét ország (Magyarország és Ukrajna) egyszerre szerepelt a jövőbeli munkavállalás célországaként (Ferenc 2015: 122). A korcsoportok migrációs tervei közötti különbségeket a jelen kutatás adatain is teszteljük.

\section{Hipotézisek}

Feltételezésünk szerint inkább a fiatalok és az egyedülálló pedagógusok vannak jobban kitéve a migráció toló és húzó tényezőinek. A toló tényezők között, úgy gondoljuk, jelentős szerepe van a megélhetésnek, a pedagógus szakma alacsony anyagi

${ }^{5}$ Ezt jól érzékelteti, hogy a Kárpátaljai Magyar Pedagógus Szövetség a megüresedett állásokat honlapján meg is hirdette: http://kmpsz.uz.ua/oktatasi-intezmenyek/allasajanlatok.html (Utolsó megtekintés: 2018.01.13.) 


\section{TEMATIKUS TANULMÁNYOK - Kárpátalja társadalma}

megbecsültségének. Kutatásunkkal a magyar állampolgársággal való rendelkezés és a nyelvtudás hatását is megvizsgáljuk a migrációs szándékokra: egyúttal azt a hipotézist fogalmazzuk meg, hogy a magyar állampolgársággal járó európai uniós útlevél megkönnyíti és előmozdítja a migrációt, az alacsony ukrán nyelvtudás, illetve más nyugati idegen nyelvek ismerete szintén a migrációt felerősítő faktorok.

\section{5. Általános szociodemográfiai jellemzők}

A kérdőívet kitöltők nemi megoszlása a pedagógusi szakma elnőiesedését mutatja Kárpátalján is: $15 \%$ a férfiak aránya és $85 \%$ a nőké. Ugyan a nemzetközi példák érdekes különbségeket tártak fel férfiak és nők között, az alacsony elemszám miatt ebben a kutatásban nemi összehasonlítást nem áll módunkban végezni.

A pedagógusok 73\%-a falusi, 27\%-a városi lakos, ami leginkább arra vezethető vissza, hogy a kárpátaljai magyarok döntően falusi környezetben élnek. A kérdőív kitöltői öt nagyobb földrajzi körzet között oszlanak meg (1. táblázat), azt is leképezve, hogy hol a legsűrűbb a magyar nyelvű oktatási hálózat.

1. táblázat. Az adatközlők megoszlása földrajzi térségek között (fő/\%)

\begin{tabular}{|l|c|c|}
\hline \multicolumn{1}{|c|}{ Körzet } & Pedagógusok száma & $\%$ \\
\hline Beregszászi járás & 152 & 45,0 \\
\hline Felső-Tisza-vidék & 17 & 5,0 \\
\hline Munkácsi járás & 43 & 12,7 \\
\hline Nagyszőlősi járás & 54 & 16,0 \\
\hline Ungvári járás & 72 & 21,3 \\
\hline Összesen & 338 & 100,0 \\
\hline
\end{tabular}

Forrás: Saját szerkesztés

A megkérdezett pedagógusok átlagéletkora: 42 év. A legkevesebben a 30 év alatti, pályakezdő pedagógusok vannak, a legtöbben pedig 30-40 év közöttiek. Ukrajnában a nyugdíjkorhatár 60 (nők esetében 58,5) év. Ez alapján megállapíthatjuk, hogy a megkérdezett pedagógusok majd 10\%-a, vagyis 33 fó érte már el a nyugdíjas kort, de mellette folytatta pedagógusi munkáját. 
www. metszetek.unideb.hu

\section{TEMATIKUS TANULMÁNYOK - Kárpátalja társadalma}

1. ábra. A pedagógusok életkor szerinti csoportosítása (\%; N=333)

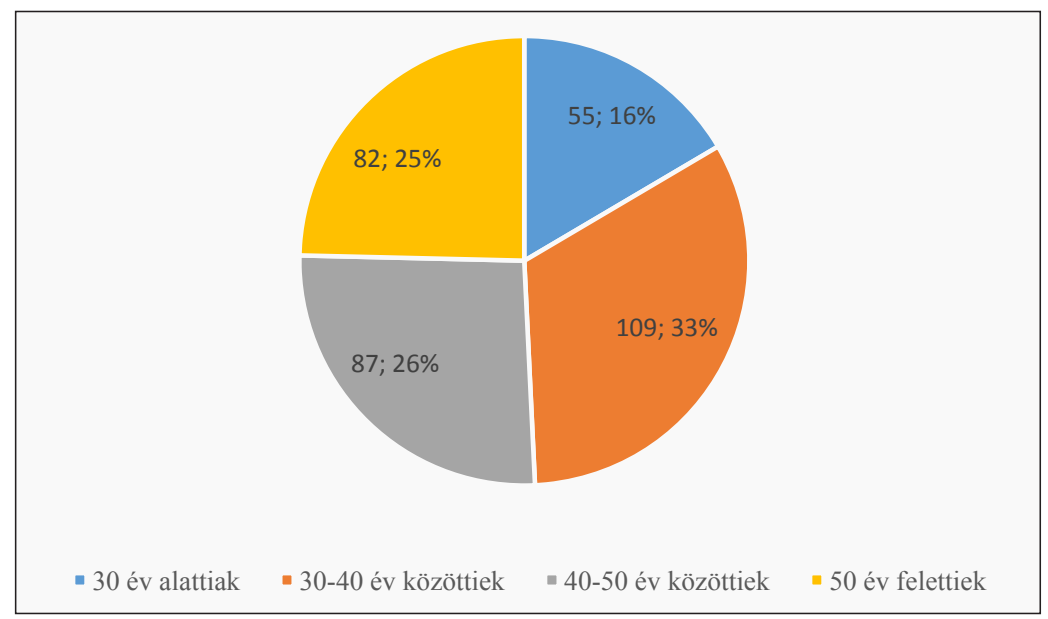

Forrás: Saját szerkesztés

A pályán eltöltött idő átlaga 19 év, szélső értékei az 1 éve dolgozó és az 57 éve dolgozó pedagógus. Az igazán pályakezdők, akik még öt éve sem dolgoznak pedagógusként, viszonylag kevesen vannak, ezért 10 évenként bontottuk az adatainkat, hogy viszonylag kiegyensúlyozott alcsoportokat kapjunk a pályán eltöltött évek tekintetében, azzal a megalkuvással, hogy a 30 évnél több időt a pályán eltöltőket (a 30-57 év tartományt) egy csoportba soroljuk a kevés elemszám miatt.

2. ábra. A pedagógusok pályán eltöltött idő szerinti megoszlása (\%; N=330)

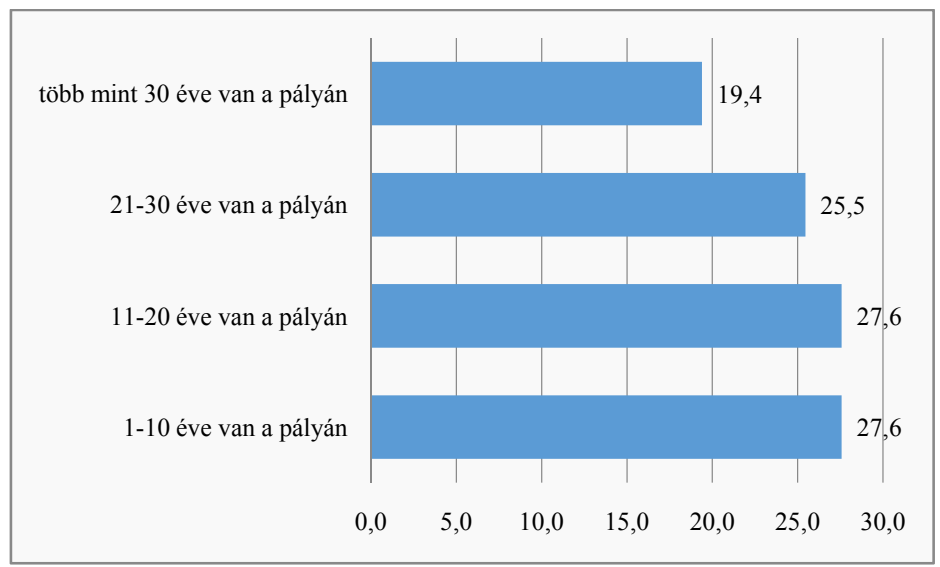

Forrás: Saját szerkesztés 
www. metszetek.unideb.hu

\section{TEMATIKUS TANULMÁNYOK - Kárpátalja társadalma}

A megkérdezett pedagógusok több mint fele (56\%) felső tagozatos tanár, 22\%-uk alsó tagozatos, és 13\% dolgozik óvodapedagógusként. Az egyéb kategóriát jelölték (9\%) be azok a pedagógusok, akik napköziben tanítanak, vagy szervező-tanárként dolgoznak.

\section{Elvágyódás, elvándorlás a pedagógusok között}

Mivel kutatásunk egyik fő célja annak feltárása, hogy a kárpátaljai pedagógusok elvágyódása, elvándorlása szülőföldjükről folytatódott-e 2017-ben, megkérdeztük őket, hogy mennyire foglalkoztatja őket a végleges kitelepedés gondolata? A kérdésre 323 válaszadó közül 32\%, vagyis 104 fő mondta azt kategorikusan, hogy nem telepedne ki. További 130 fő (40\%) még nem gondolkodott rajta. Ez mindenképpen azt jelzi, hogy a kárpátaljai pedagógusok 72\%-a, bár elégedetlen helyzetével, de nem gondolkodik a kitelepedésen, vagy nem telepedne ki külföldre. A veszélyeztetettebb kategóriát az a 84 fó jelenti (26\%), akinek már vannak elképzelései a kitelepedéssel kapcsolatban, de még nem tett konkrét lépéseket. A kitelepedés érdekében már konkrét lépéseket is tett pedagógusok száma alacsony, mindösszesen 5 fót (2\%-ot) azonosítottunk be.

3. ábra. Gondolt-e már arra, hogy végleg kitelepedjen külföldre? (fö, N=323)

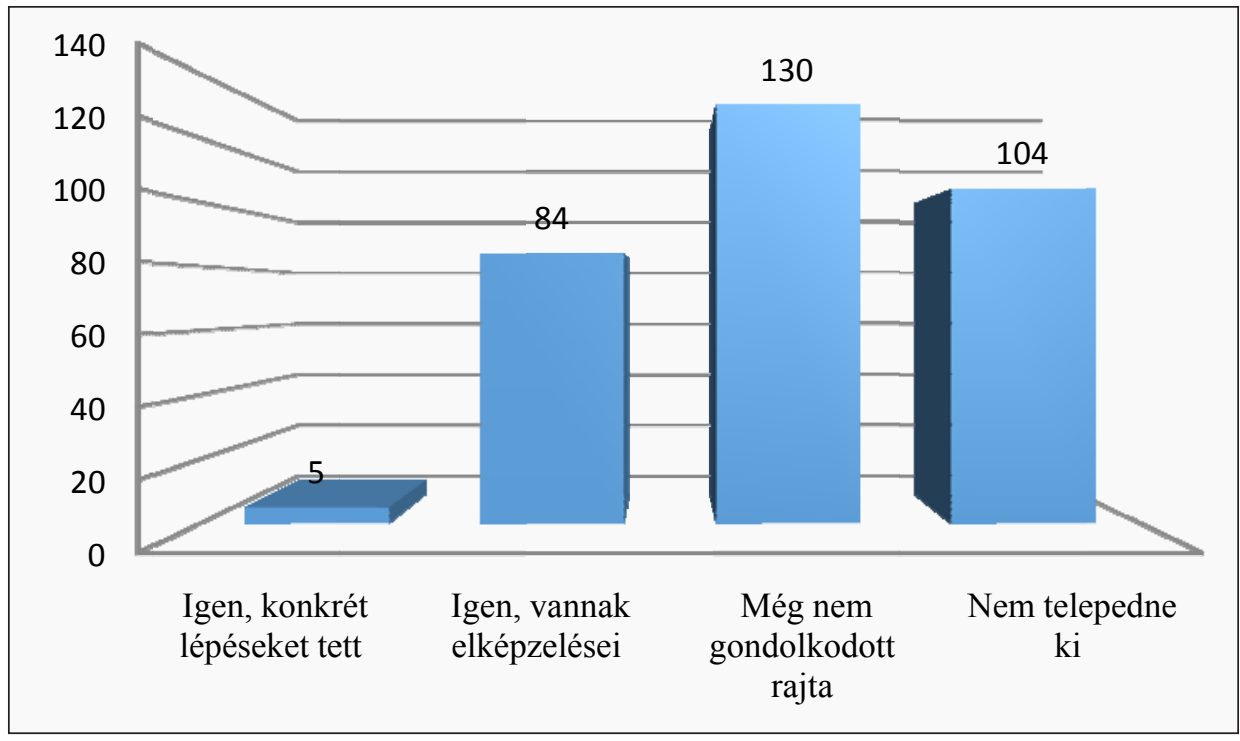

Forrás: Saját szerkesztés 


\section{TEMATIKUS TANULMÁNYOK - Kárpátalja társadalma}

Az adatok azt mutatják, hogy szignifikáns eltérés (Khí-négyzet próba: 0,002) van a korcsoportok között: bár a 40 év feletti, két legidősebb korcsoport között oszlik el az öt fonnyi „konkrét lépéseket tett” csoport, de a lappangó, még csak elképzeléssel rendelkezők/vagy ezen nem gondolkodók között minél fiatalabb valaki annál inkább vannak migrációs elképzelései: pl. a legfiatalabb, 30 év alatti korosztály teszi ki közel a felét (49\%) annak a teljes mintára vetített 26\%-nak, aki rendelkezik migrációs elképzelésekkel.

2. táblázat. Kitelepedési tervek korcsoportok szerint (\%, N=321)

\begin{tabular}{|l|c|c|c|c|}
\hline \multicolumn{1}{|c|}{ Korcsoport } & $\begin{array}{c}\text { Igen, konkrét } \\
\text { lépéseket tett }\end{array}$ & $\begin{array}{c}\text { Igen, vannak } \\
\text { elképzelései }\end{array}$ & $\begin{array}{c}\text { Még nem } \\
\text { gondolkodott rajta }\end{array}$ & $\begin{array}{c}\text { Nem } \\
\text { telepedne ki }\end{array}$ \\
\hline 30 év alattiak & $0,0 \%$ & $\mathbf{4 9 , 1 \%}$ & $24,5 \%$ & $26,4 \%$ \\
\hline 30-40 év közöttiek &, $9 \%$ & $27,1 \%$ & $37,4 \%$ & $34,6 \%$ \\
\hline 40-50 év közöttiek & $\mathbf{2 , 4 \%}$ & $18,3 \%$ & $51,2 \%$ & $28,0 \%$ \\
\hline 50 év felettiek & $\mathbf{2 , 5 \%}$ & $16,5 \%$ & $43,0 \%$ & $38,0 \%$ \\
\hline
\end{tabular}

Forrás: Saját szerkesztés

Az elvándorlási tervek 82\%-ban Magyarországra vonatkoznak. Ugyanakkor a mintegy 10\%-nyi „nem tudom” válasz is jelzi, hogy sokan még olyan mértékben sem haladtak előre a tervezésben, hogy az országot meg tudják nevezni, ahová kitelepednének. A konkrét tervekkel vagy elképzelésekkel rendelkező 89 fónél a kivándorlás célországa nagyrészt Magyarország: a konkrét lépéseket már megtettek közül mindenki, az elképzelésekkel rendelkezők közül pedig 86\% jelölte meg ezt az opciót.

4. ábra. A migráció célországa (\%; $\mathrm{N}=254)$

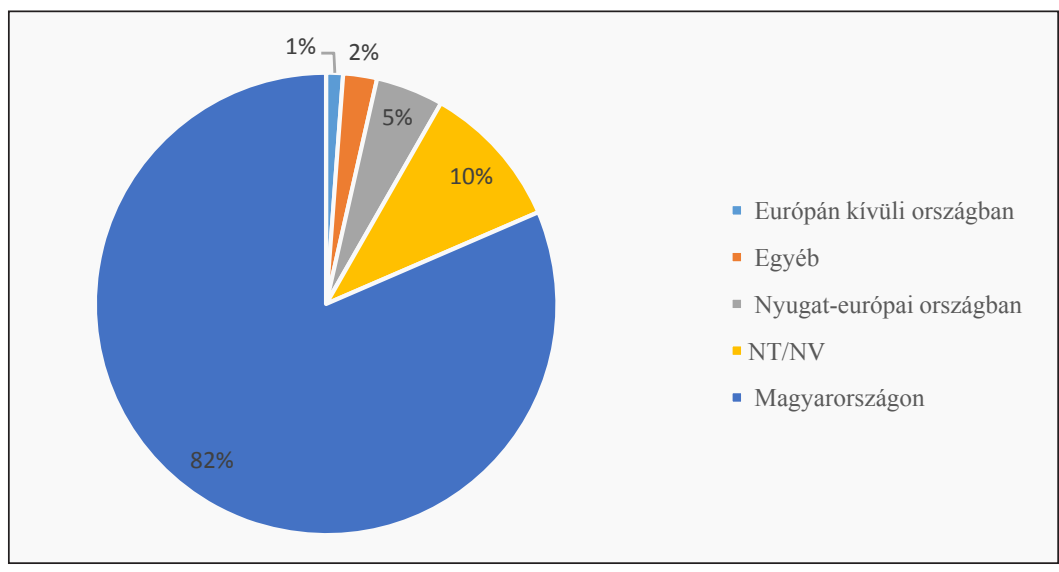

Forrás: Saját szerkesztés 


\section{TEMATIKUS TANULMÁNYOK - Kárpátalja társadalma}

A migrációt fontolgatók a legtöbben az anyagi elégedetlenség miatt hagynák el az országot, ezt az okot a mintából majdnem minden harmadik személy megjelölte. Azt látjuk tehát, hogy az ukrán válság éveiben a megélhetési kérdések a legégetőbbek Kárpátalján. Ezt követi a családi, párkapcsolati motiváció. A következőkben ezt a két nagyobb motivációs témakört járjuk körül részletesebben.

5. ábra. Milyen okból hagyná el Kárpátalját? (N=255)

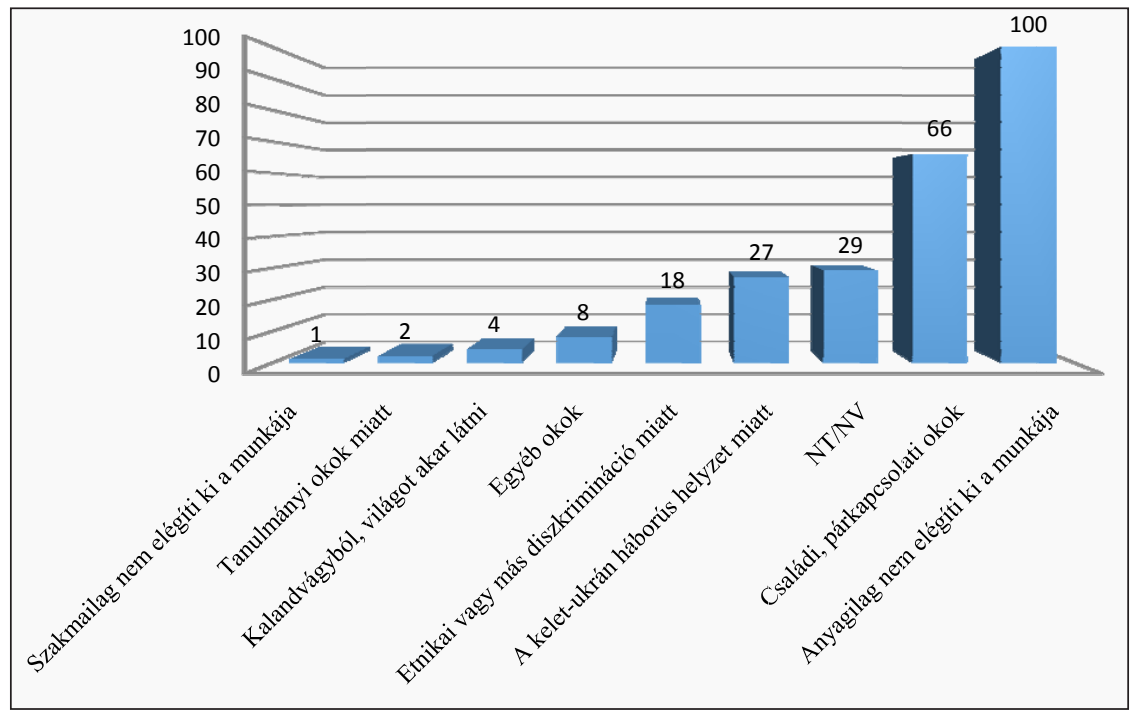

Forrás: Saját szerkesztés

A kelet-ukrajnai háborús helyzet és az etnikai diszkrimináció miatt is többen a külföldre költözést látják reális opciónak. A kalandvágy, a tanulmányi okok, vagy a szakmai elégedetlenség kevés esetben jelent motivációt a külföldre költözésben a kárpátaljai pedagógusok számára.

\subsection{MEGÉLHETÉSI KÖRÜLMÉNYEK, ANYAGI HELYZET}

A megélhetési körülmények felmérésére használtuk az alábbi, önbevalláson alapuló, szubjektív anyagi helyzetre vonatkozó kérdést. A válaszadók fele úgy véli, épp a határán van a megélhetésnek, $4 \%$ viszont úgy érzi, már ez a leírás is túlzás a helyzetére, hiszen hónapról-hónapra anyagi gondjai vannak. 44\% csak beosztással tud kijönni a havi bevételeiből. Mindössze 2\% azok aránya, akik anyagi gondok nélkül élnek. A havi bevételre vonatkozó kérdésünknél azt az eredményt kaptuk, hogy a pedagógusok átlagosan havi 5000 hrivnyából (kb. 44650 forint) gazdálkodnak. Az egész 
www. metszetek.unideb.hu

\section{TEMATIKUS TANULMÁNYOK - Kárpátalja társadalma}

családra vonatkozó átlag havi kereset pedig 8000 hrivnyára (kb. 71440 forintra) tehető. ${ }^{6}$

6. ábra. Hogy érzi, családja anyagilag... (\%, N=324)

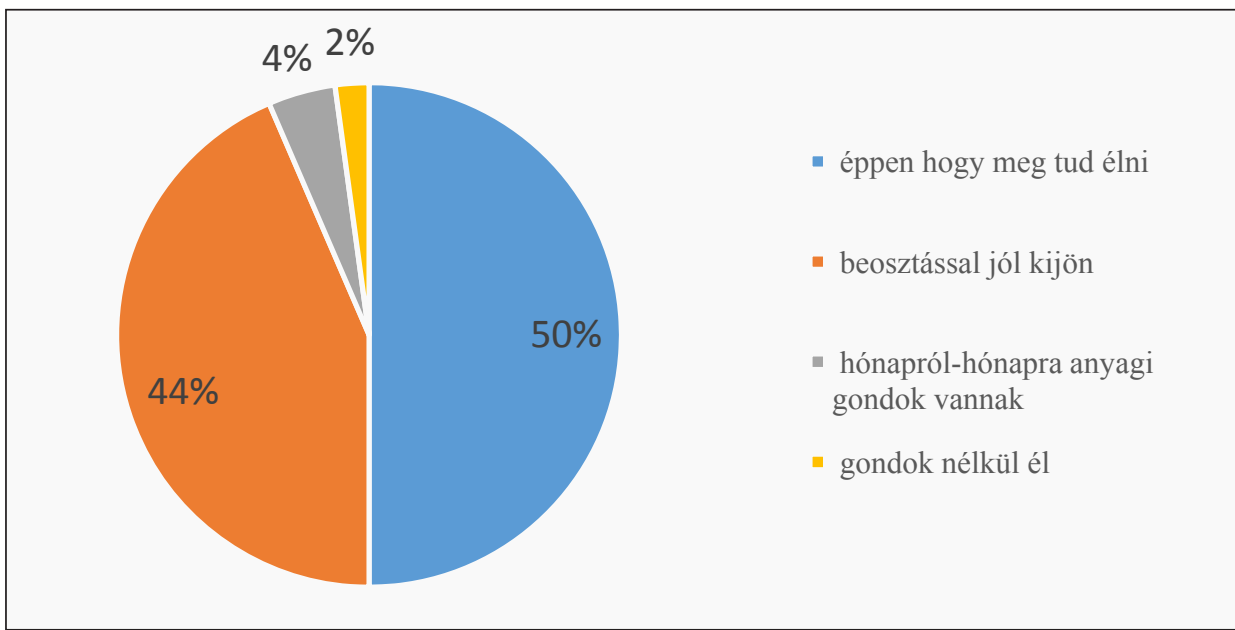

Forrás: Saját szerkesztés

Ugyan nem szignifikáns a különbség a pedagógusok migrációs szándéka és a megélhetésük között, de azt látjuk, hogy aki gond nélkül meg tud élni, arra leginkább a kitelepedés elutasítása jellemző (71\%). Ugyanez jellemző azokra, akik beosztással jól kijönnek: 38\%-uk még nem gondolkodott a kitelepedésen, 41\% pedig elutasítja azt. Azok között, akik épp meg tudnak élni, vagy hónapról hónapra gondjaik vannak, akad 15-23\% olyan, aki még így sem telepedne ki. Ebben a két anyagilag nehezebb kategóriában azt látjuk, hogy közel 50\%-uk inkább nem gondolkodik a kitelepedésen, de minden harmadik ember már rendelkezik elképzelésekkel.

${ }^{6} \mathrm{~A}$ forintosítás alapjául az MNB kutatás idejére vonatkozó középárfolyama szolgált: https://www. mnb.hu/arfolyamok. A havi bevételre vonatkozó kérdés esetén adatközlőink jelentős része (19\%) élt a válaszmegtagadás lehetőségével, és feltételezhetjük, hogy az itt megadott összegek is a valóságnál alacsonyabb értékeket tükröznek. A nehéz gazdasági viszonyok miatt adatközlőink félnek bevallani tényleges keresetüket, mert ezek egy része nem feltétlenül törvényes keretek között (pl. külföldi, nem bejelentett vendégmunka, határ menti kereskedelem) teremtődik meg, a kiugró érték pedig a környezet rosszallását váltaná ki. 
www. metszetek.unideb.hu

\section{TEMATIKUS TANULMÁNYOK - Kárpátalja társadalma}

3. táblázat. A család anyagi helyzetének hatása a migrációs szándékokra (\%,N=313)

\begin{tabular}{|l|c|c|c|c|}
\hline & $\begin{array}{c}\text { Igen, konkrét } \\
\text { lépéseket tett }\end{array}$ & $\begin{array}{c}\text { Igen, vannak } \\
\text { elképzelései }\end{array}$ & $\begin{array}{c}\text { Még nem gon- } \\
\text { dolkodott rajta }\end{array}$ & $\begin{array}{c}\text { Nem tele- } \\
\text { pedne ki }\end{array}$ \\
\hline Gondok nélkül él & $0,0 \%$ & $14,3 \%$ & $14,3 \%$ & $71,4 \%$ \\
\hline Beosztással jól kijön & $0,0 \%$ & $20,6 \%$ & $38,2 \%$ & $41,2 \%$ \\
\hline $\begin{array}{l}\text { Éppen hogy meg tud } \\
\text { élni }\end{array}$ & $3,2 \%$ & $30,6 \%$ & $43,3 \%$ & $22,9 \%$ \\
\hline $\begin{array}{l}\text { Hónapról hónapra anya- } \\
\text { gi gondok vannak }\end{array}$ & $0,0 \%$ & $38,5 \%$ & $46,2 \%$ & $15,4 \%$ \\
\hline
\end{tabular}

Forrás: Saját szerkesztés

Adatközlőink személyes anyagi helyzetét természetesen a teljes ukrajnai kontextusban érdemes megítélni. A pedagógusok - a fenti adatok ellenére is - úgy érzik, személyes és munkahelyi helyzetük kevésbé romlott, mint az országban élő emberek életszínvonala általában, vagy a régió és az ország gazdasági helyzete az elmúlt öt évben. A kárpátaljai pedagógusok több mint fele a személyes körülményeinek és iskolája helyzetének közelmúltbeli alakulására inkább optimistán (stagnáló vagy javuló perspektívából) tekint.

7. ábra. Az elmúlt öt évben hogyan alakult...?

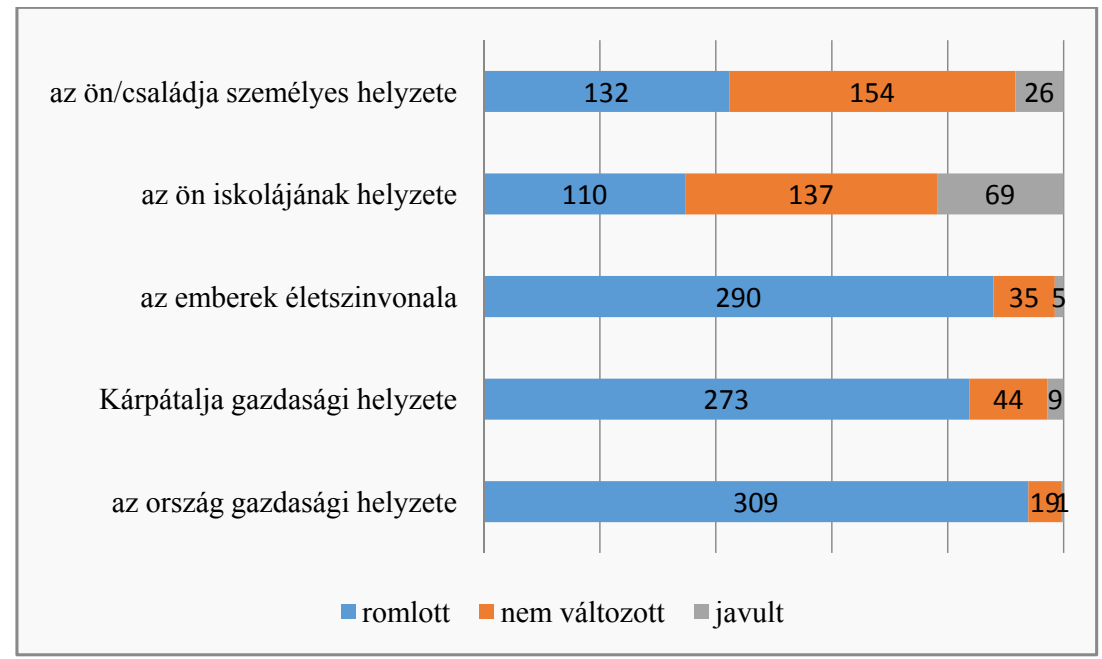

Forrás: Saját szerkesztés 


\section{TEMATIKUS TANULMÁNYOK - Kárpátalja társadalma}

A jövő megítélése is fontos szempont a kárpátaljai pedagógusok helyzetének megismerésében. Úgy tűnik, adatközlőink optimisták a jövőt illetően: a javulást jelző szürke oszloprészletek az előző diagramhoz képest, visszafogottan ugyan, de növekedni kezdtek. A személyes helyzet megítélésével összehasonlítva, az előbbiekhez hasonlóan a régiós-országos viszonyok változását illetően kevésbé optimisták az emberek, de mint a közelmúlt, úgy a közeljövő tekintetében jobb megítélést kapott a gazdasági helyzet Kárpátalján, mint országosan.

8. ábra. A következő öt évben hogyan alakul...?

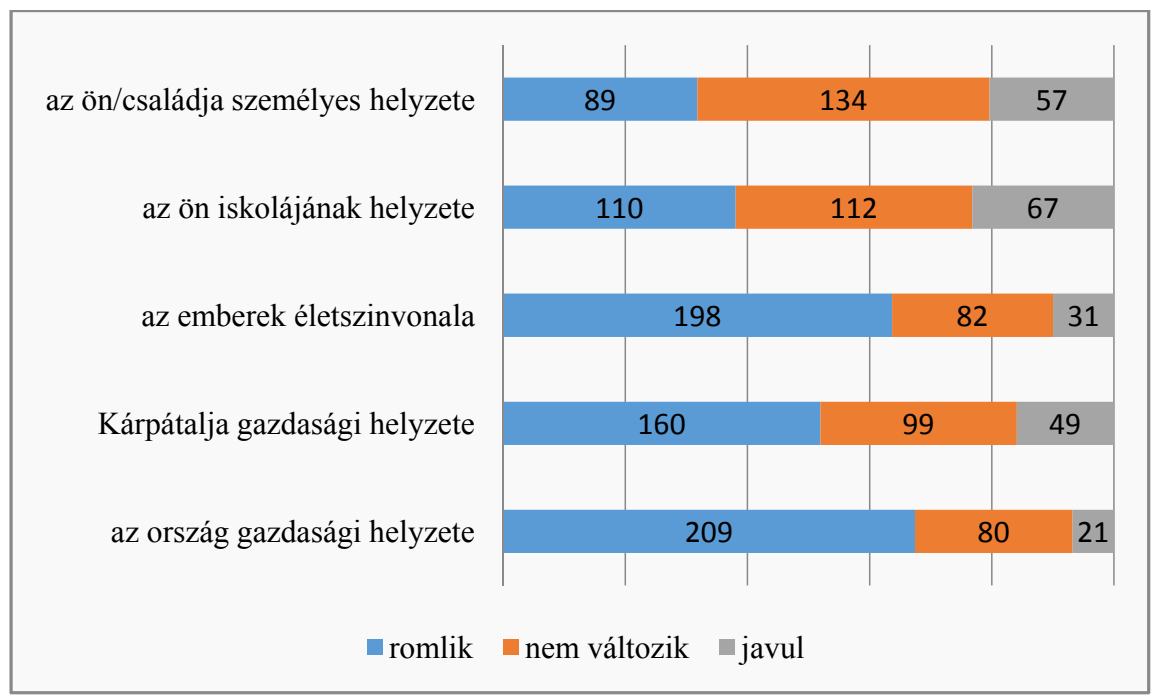

Forrás: Saját szerkesztés

\subsection{CSALÁDI HELYZET}

A biztonságérzet, a szülőföldön maradás vagy az elvágyódás - főleg egy olyan tradicionális értékekkel rendelkező régió, mint Kárpátalja tekintetében - sok esetben a családi állapottal szoros összefüggésben értelmeződik. A kárpátaljai (85\%-ban nő nemű) pedagógusok döntő többsége, pontosan $80 \%$-a házas, további 3\% együtt él valakivel. Az egyedülállók (11\%), az özvegyek (3\%) és elváltak (3\%) aránya összesen $17 \%$. 


\section{TEMATIKUS TANULMÁNYOK - Kárpátalja társadalma}

9. ábra. A pedagógusok családi állapota (\%, N=330)

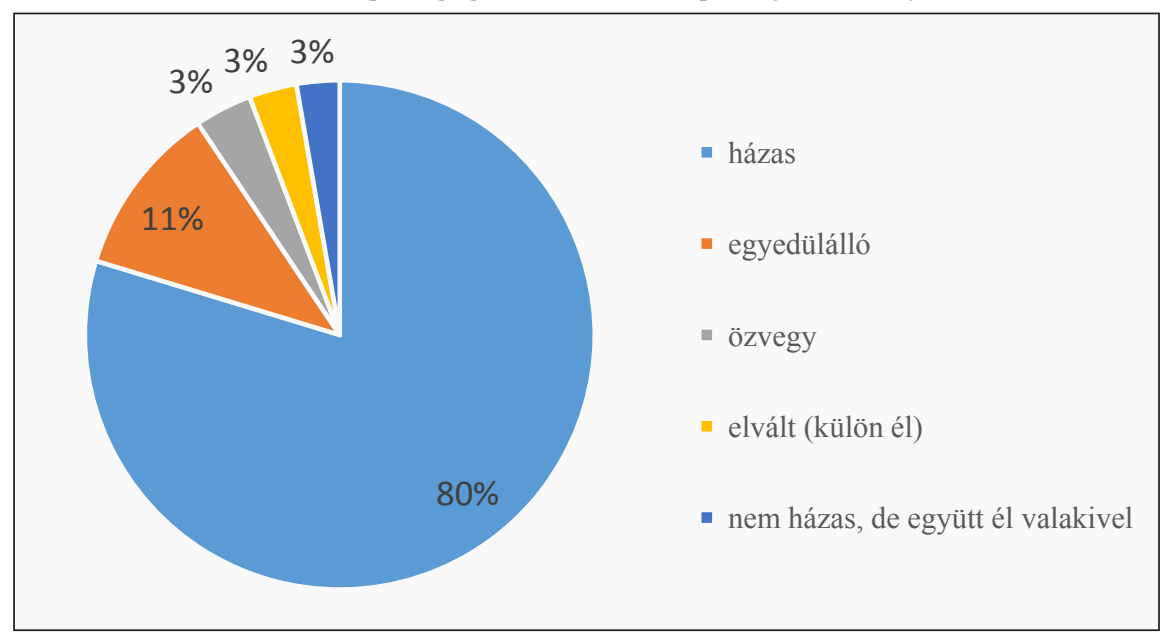

Forrás: Saját szerkesztés

A családi, párkapcsolati ok volt a második legfontosabb migrációs motiváció: 66 fő mondta azt, hogy ilyen okokból hagyná el az országot, ami összefügghet azzal, hogy a családtagok, az ukrajnai anyagi helyzet miatt már korábban elkezdtek külföldön dolgozni, s most a család is követi őket. Alanyaink közül 135-en (41\%) válaszoltak igennel arra a kérdésre, hogy él külföldön családtagjuk. Négy országot említettek ezen belül a pedagógusok: a legtöbb családtag (104) Magyarországon él, ezután Németország következik (10), majd Csehország és Anglia (6-6 fö). A külföldön élő családtagok 73\%-a munka céllal van külföldön, 11\% tanul. A legtöbb pedagógusnak (39\%) a testvére (vagyis saját generációja) van külföldön, amit a gyermekek követnek (36\%). A külföldön dolgozó házastárs viszonylag ritka (9\%). A külföldön élő családtágok általában évente többször látogatnak haza, kevesebben vannak a havi rendszerességgel hazalátogatók. Ugyanakkor adatközlőink durván $60 \%$-a úgy véli, ezek a családtagok már soha nem fognak visszatelepülni Kárpátaljára. A külföldön élő családtagok $40 \%$ esetében anyagilag támogatják a családot, de majdnem ekkora arányban jellemző az is, hogy nem küldenek és nem is kapnak anyagi támogatást a Kárpátalján élő családtagok a külföldön élőktől. 
www. metszetek.unideb.hu

\section{TEMATIKUS TANULMÁNYOK - Kárpátalja társadalma}

10. ábra. Külföldön élő családtagok (fő, $\mathrm{N}=123$ )

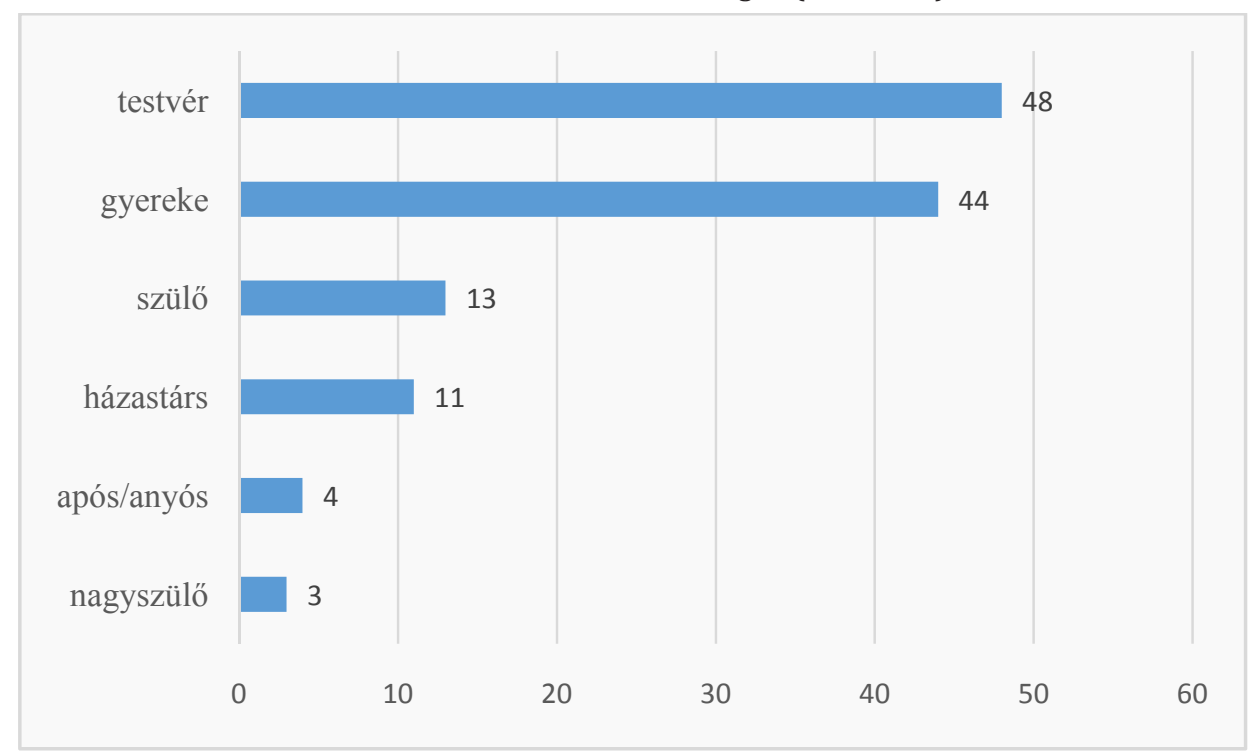

Forrás: Saját szerkesztés

Ha a fenti migrációs adatokat a pedagógusok családi állapotával összevetjük, akkor ugyan nem találunk az egyedülállók és a családosok viszonylatában szignifikáns eltérést, de a táblázat adatai azt mutatják, hogy mintegy 5\%-kal többen vannak a családos kategóriában a kitelepülni vágyók (28\%) az egyedülállókhoz képest (23\%). Ezen kívül 77\% egyedülálló és 72\% családos mond inkább nemet a kitelepedésre (együtt a „még nem gondolkodott rajta” és a „nem telepedne ki” kategóriák). Vagyis, úgy tűnik a kitelepedés inkább a családosokat vonzza.

4. táblázat. Kitelepedési tervek a családi állapot szerint (\%, N=318)

\begin{tabular}{|l|c|c|c|c|}
\hline & $\begin{array}{c}\text { Igen, konkrét } \\
\text { lépéseket tett }\end{array}$ & $\begin{array}{c}\text { Igen, vannak } \\
\text { elképzelései }\end{array}$ & $\begin{array}{c}\text { Még nem gon- } \\
\text { dolkodott rajta }\end{array}$ & Nem telepedne ki \\
\hline Egyedülálló & $0,0 \%$ & $22,8 \%$ & $31,6 \%$ & $45,6 \%$ \\
\hline Családos/együtt él & $1,9 \%$ & $26,4 \%$ & $42,5 \%$ & $29,1 \%$ \\
\hline Összesen & $1,6 \%$ & $25,8 \%$ & $40,6 \%$ & $32,1 \%$ \\
\hline
\end{tabular}

Forrás: Saját szerkesztés 


\section{TEMATIKUS TANULMÁNYOK - Kárpátalja társadalma}

A pedagógusok 81\%-nak (272 főnek) már gyereke is van, több mint fele arányban kettő, vagy annál több gyermek.

11. ábra. Hány gyereke van? (\%; $\mathrm{N}=272)$

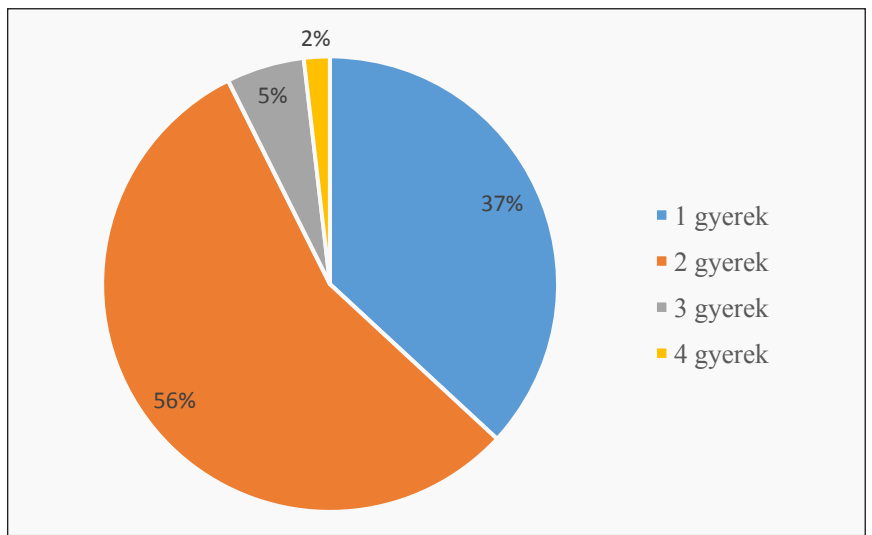

Forrás: Saját szerkesztés

A stabil családi helyzet, a gyermekek megléte egyik oldalról lehet a migráció ellen ható erő, ugyanakkor a másik oldalról, kialakulhat olyan nehéz megélhetési helyzet, amikor épp a gyermekek jövőjének biztosítása érdekében ${ }^{7}$ döntenek egész családok a migráció mellett. A gyermekkel való rendelkezés szerint sincs szignifikáns különbség az egyes csoportok kitelepedési szándékai között, de egy picivel többen vannak a gyerekesek (73\%) a gyerekkel nem rendelkezőknél (70\%) a két kitelepedést ellenző kategóriában. Ugyanakkor a nem telepedne ki kategóriában jóval többen vannak a gyerektelenek (39\% a 31\%-kal szemben).

5. táblázat. Kitelepedési tervek a gyermekkel való rendelkezés szerint (\%, N=322)

\begin{tabular}{|l|c|c|c|c|c|}
\hline \multirow{2}{*}{ Van gyereke } & $\begin{array}{c}\text { Igen, konkrét } \\
\text { lépéseket tett }\end{array}$ & $\begin{array}{c}\text { Igen, vannak } \\
\text { elképzelései }\end{array}$ & $\begin{array}{c}\text { Még nem gon- } \\
\text { dolkodott rajta }\end{array}$ & $\begin{array}{c}\text { Nem } \\
\text { telepedne ki }\end{array}$ & Összesen \\
\cline { 2 - 6 } & 5 & 65 & 111 & 80 & 261 \\
\hline \multirow{2}{*}{ Nincs gyereke } & $1,9 \%$ & $24,9 \%$ & $42,5 \%$ & $30,7 \%$ & $100,0 \%$ \\
\cline { 2 - 6 } & 0 & 18 & 19 & 24 & 61 \\
\hline
\end{tabular}

Forrás: Saját szerkesztés

${ }^{7}$ Lásd később a magyar állampolgárság igénylése mögött is ez az egyik leginkább jellemző motiváció. 


\section{TEMATIKUS TANULMÁNYOK - Kárpátalja társadalma}

Arra vonatkozóan, hogy adatközlőink környezetükben milyen hangulatot tapasztalnak a menni vagy maradni dilemmájában, szintén fogalmaztunk meg kérdést. Láthatjuk, hogy a családi, baráti, munkatársi környezetben csak „néhányan” (szürke oszloprész) tervezik a külföldre költözést. Érdekes módon a közeli családtagok körében igen magas a „szinte senki” és a „senki” kategóriák részaránya, ami ellentmondásos lehet azzal a korábbi megállapítással, hogy családi okokból készülnek egyesek elhagyni az országot. Lehetséges, hogy a már elköltözött családtagokra az adatközlők nem vonatkoztatták ezt a kérdést.

12. ábra. A környezet migrációs hajlandósága (\%)

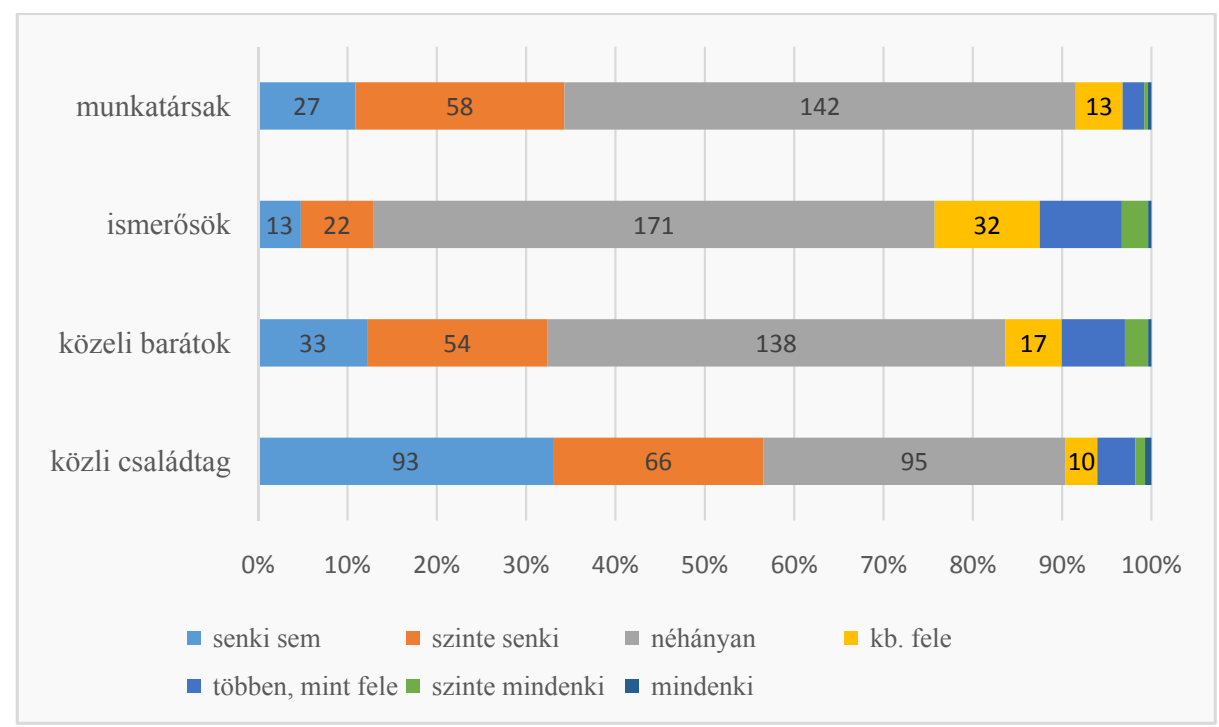

Forrás: Saját szerkesztés

A (még otthonlévő?) munkatársak és a közeli barátok egyharmadára szintén az az állítás igaz, hogy senki, vagy szinte senki nem készül külföldre közülük. A legmagasabb migrációs hajlandóság az adatközlők távolabbi ismerősi körére jellemző.

\section{Társadalmi-politikai környezet}

Az eddig elemzett, inkább személyes életkörülmények mellett a tágabb társadalmi-politikai környezet vizsgálatára is érdemes figyelmet fordítanunk. Különösen azért, mert a a kelet-ukrajnai háborús helyzet és az etnikai diszkrimináció is megjelent a migrációt kiváltó okok között. A kérdőívezés során megkértük a pedagóguso- 


\section{TEMATIKUS TANULMÁNYOK - Kárpátalja társadalma}

kat, hogy mondják el, melyek a kárpátaljaiak legégetőbb, aktuális problémái. Az előre megfogalmazott problémalistát egy négyfokú skálán értékelhették az adatközlők. Az így kapott értékek hierarchiáját az alábbi diagram szemlélteti. Minél jobban közelít az adott probléma átlaga a 4-es skálaértékhez, annál inkább tartják jelentősnek azt a kárpátaljai pedagógusok. A négyfokú skála felezőértéke 2,5-nél van, vagyis minden ennél nagyobb átlag azt jelzi, a pedagógusok az adott kérdést problematikusnak látják: így kijelenthetjük, hogy az általunk felsorolt szempontok tekintetében gondok vannak, de a problémák súlyossága jól kivehető az átlagok hierarchiájából. A három legfontosabb probléma a pedagógusok szerint (1) a korrupció, (2) a keletukrajnai háborús helyzet és a korábbiakban is elemzett (3) pénztelenség és alacsony keresetek.

13. ábra. Melyek a kárpátaljaiak legsúlyosabb problémái?

(1-4-es skálán kapott átlagok, ahol 1= egyáltalán nem ért egyet, 4=teljes mértékben egyet ért)

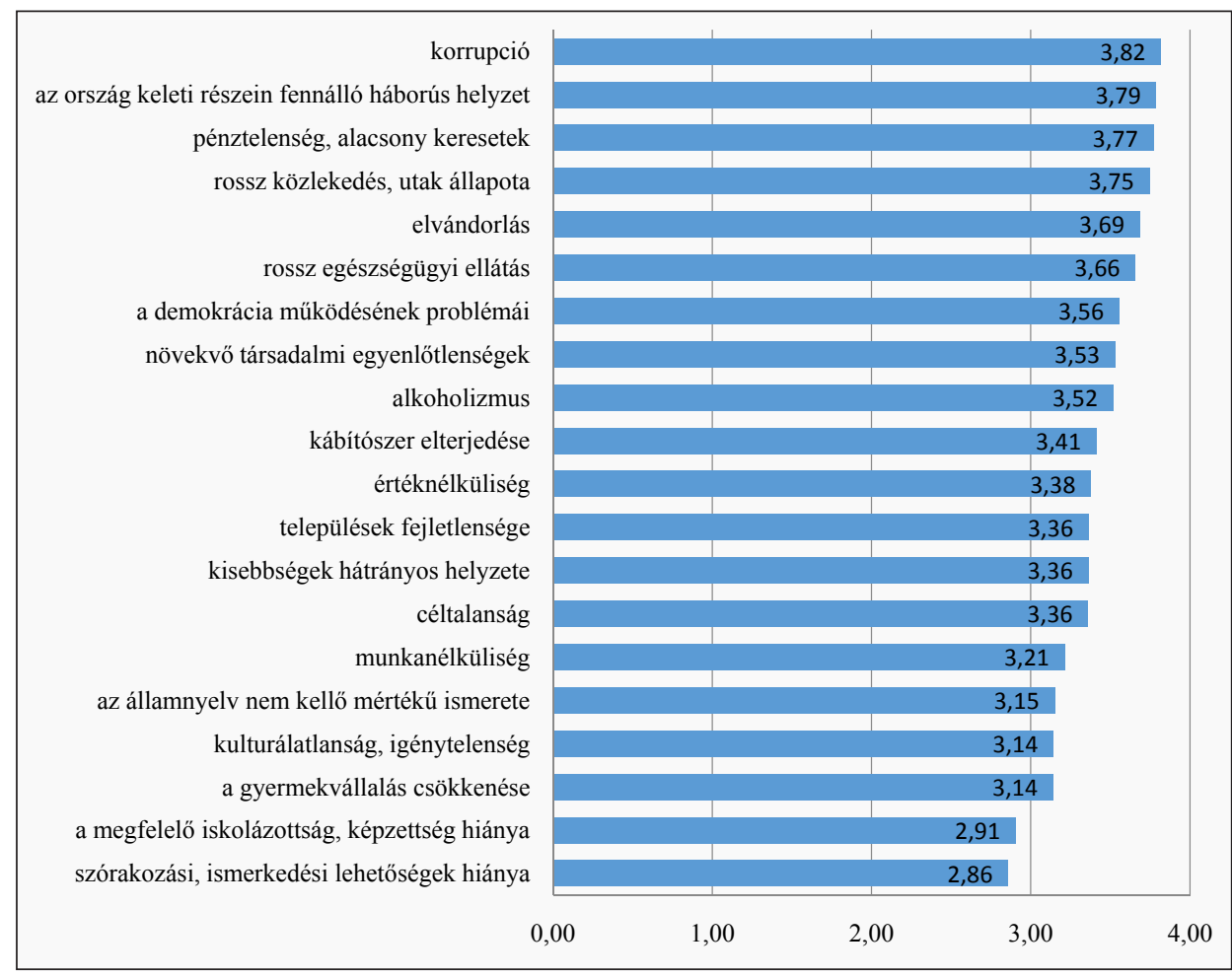

Forrás: Saját szerkesztés 
www. metszetek.unideb.hu

\section{TEMATIKUS TANULMÁNYOK - Kárpátalja társadalma}

14. ábra. Az Ön iskolájában a felsorolt dolgok mennyire számítanak problémának? (1-4-es skálán kapott átlagok, ahol 1 = egyáltalán nem ért egyet, 4 = teljes mértékben egyet ért)

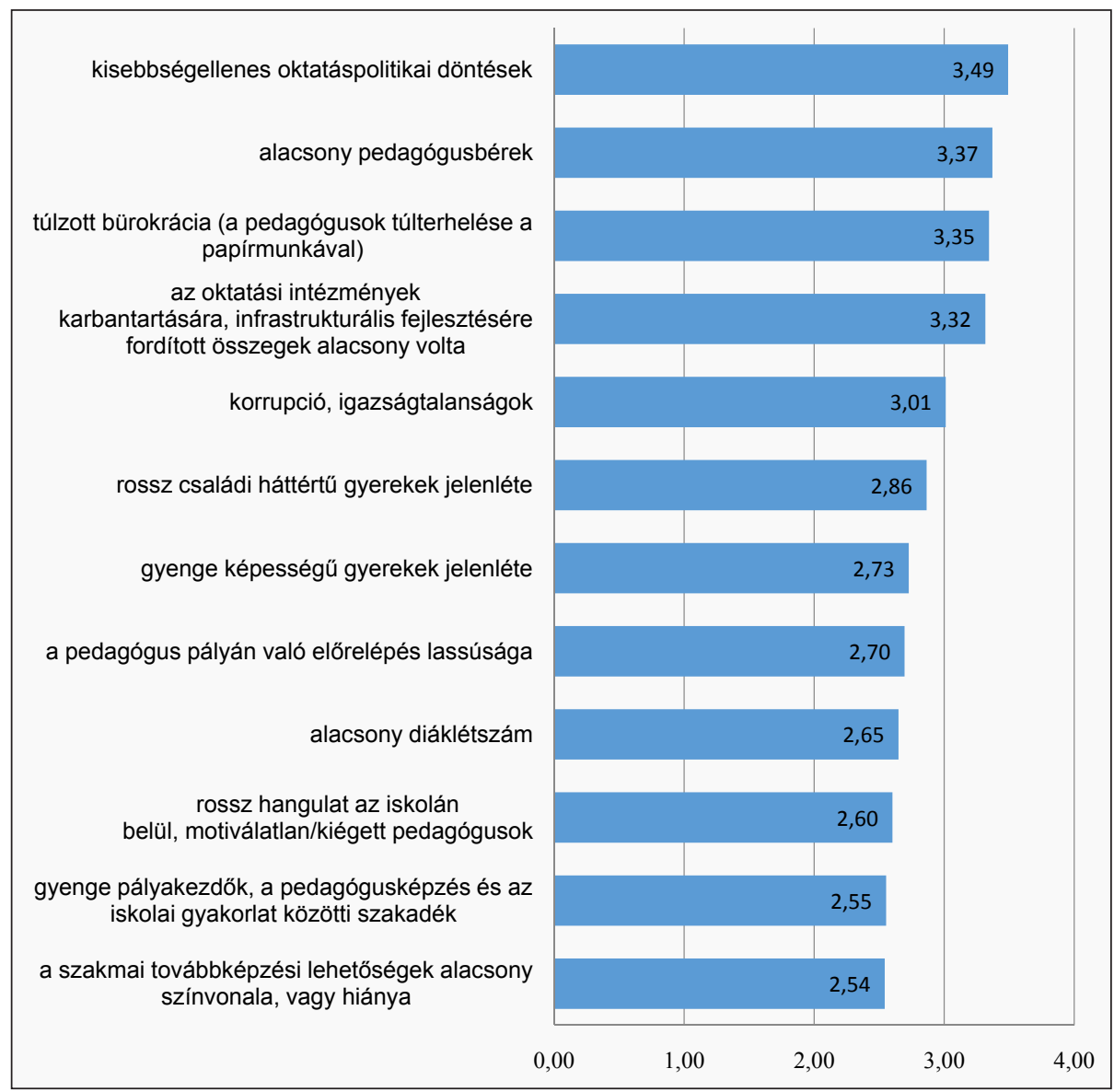

Forrás: Saját szerkesztés

Az általános szinten túl a pedagógusokat arra is megkértük, hogy mondják el, mit tartanak a legsúlyosabb problémának a kárpátaljai magyar oktatást illetően, a saját iskolájuk szűrőjén keresztül szemlélve azt. Felmérésünk épp 2017 elejére, arra az időszakra esett, amikor több kisebbségellenes törvénytervezet is az ukrán parlament elé került, ezért nem meglepő, hogy a problémák között első helyen említették (1) a kisebbségellenes politikai döntéseket, amelyek a kisebbségi nyelveken folyó 


\section{TEMATIKUS TANULMÁNYOK - Kárpátalja társadalma}

oktatást próbálja ellehetetleníteni. ${ }^{8}$ A problémák sorrendje (2) az alacsony pedagógusbérekkel és (3) a túlzott bürokráciával folytatódik. Viszonylag magas átlagértéket kapott még (azaz problémának számít) az intézmények karbantartására, fejlesztésére jutó összegek alacsony volta.

Elgondolkodtató, hogy amíg a pedagógusok megélhetési és politikai problémákkal vannak elfoglalva, addig az iskolai feladatokra (a diákok családi háttérének kezelésére, a pedagógusok motiválására, a pályakezdők mentorálására, az önfejlesztésre szakmai továbbképzéseken) nehezebb fókuszálni.

15. ábra. Van-e a pedagógus munkakör mellett másik megélhetési forrása is? (\%; N=322)

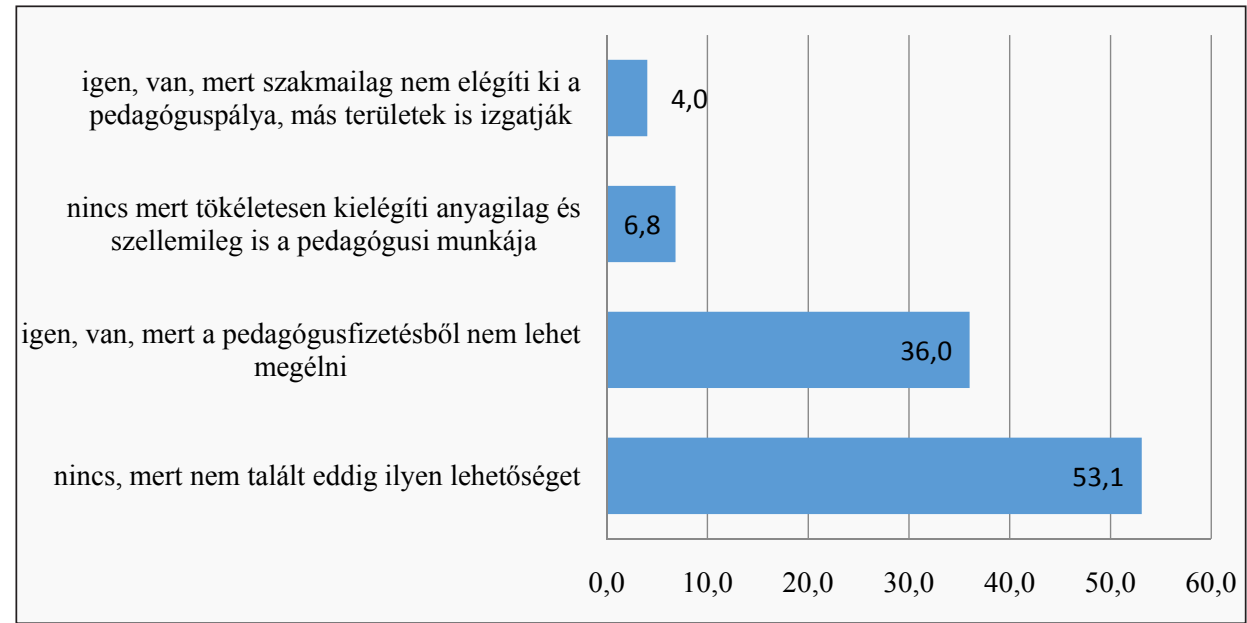

Forrás: Saját szerkesztés

Az eddig elemzett kérdések rámutattak, hogy az egyik legsúlyosabb probléma az alacsony keresetekkel van összefüggésben. Ugyanakkor fontos látni, hogy a pe-

${ }^{8}$ A kutatás idején érzékelhető oktatáspolitikai problémák összefoglalásaként lást pl. Orosz 2017. A felmérés óta a kisebbségi nyelvű oktatás lehetőségeinek korlátozása még negatívabb irányba fordultak. 2017. szeptember 28-án hatályba lépett az az oktatási kerettörvényt, amely a kisebbségek jogai kapcsán súlyos visszalépéseket tartalmaz. A 7. cikkely, amely az oktatás nyelvéről szól, ugyanis a tizenkét éves középfokú oktatásból csak az alsó harmadban (az óvodai és az elemi iskolai szinten, 1-4. osztály) engedélyezi a nemzeti kisebbségek anyanyelven történő oktatását. Az általános, a középiskola és a felsőoktatás tannyelvévé viszont kizárólag az ukránt teszi. Ezeken a szinteken a törvény külön engedélyhez köt minden ettől eltérő tannyelvű oktatást. Vagyis, elméletben, lehetséges a nemzeti kisebbségek nyelvének használata valamilyen mértékben itt is, ha összegyűlnek erre vonatkozóan a „megfelelő számú” kérelmek, de arra nincs semmilyen garancia, hogy ezeket el is fogadják, s ha igen, milyen mértékben tesznek neki eleget. Emellett a középső és felsőbb szinteken az állam csupán a „kisebbség nyelvének tanulásához” garantál jogot. A törvény magyar nyelvű fordítását lásd: Dokumentum. Ukrajna 2017. szeptember 5-én kelt 2145-VIII. sz. törvénye „Az oktatásról”. 


\section{TEMATIKUS TANULMÁNYOK - Kárpátalja társadalma}

dagógusok szakmai elégedettségével kapcsolatban mit mutat a felmérés. Ugyanis a pályaelhagyást, vagy a migrációt nem csak az anyagi elégedetlenség, hanem a szakmai kiégés is nagyban előmozdíthatja. A kárpátaljai pedagógusokat megkérdeztük, hogy van-e más megélhetési forrásuk a pedagógusi munka mellett, $\mathrm{s}$ ha van, akkor azt anyagi vagy szakmai megfontolásból tartják fenn. Láthatjuk, hogy a két „igen, van más munkája is" állításra összesen 40\%-nyian válaszoltak megerősítően: ezek közül azonban 36\% azok aránya, akik megélhetési szempontokból tartanak igényt a kiegészítő keresetre, s csupán 4\%-nyian tekintenek a másik munkára olyan szakmai erőforrásként, amit a pedagógusi pályától nem kapnak meg.

60\%-nyian vannak azok, akiknek nincs kiegészítő munkájuk, de látni kell, hogy közülük kevés az, aki nem is szeretne ilyen munkát találni, mert anyagilag és szellemileg is kielégítené a munkája (7\%). Sokkal többen vannak azok (53\%), akiknek azért nincs másodállása, mert még nem talált ilyen lehetőséget.

Kutatásunk feltárta azt is, hogy a kárpátaljai pedagógusok pedagógiai identitásának egyik legfontosabb eleme a tanított tantárgyak szeretete, de nem sokkal ezután, a még „nagyon fontos” (3,5-4 közötti értéktartomány) kategóriában szerepel a gyerekekkel való közös munka szeretete.

16. ábra. A pedagógusok szakmai elégedettsége

(1-4-es skálán kapott átlagok, ahol 1= egyáltalán nem ért egyet, 4=teljes mértékben egyet ért)

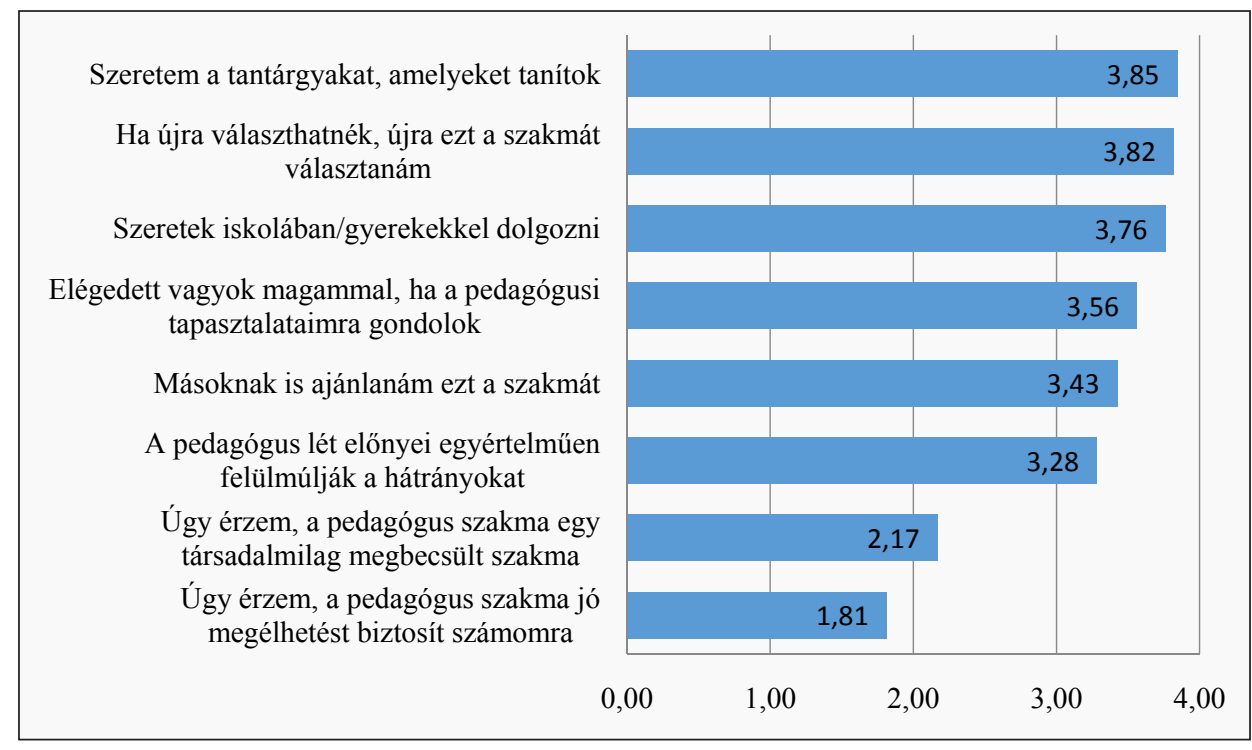

Forrás: Saját szerkesztés 


\section{TEMATIKUS TANULMÁNYOK - Kárpátalja társadalma}

Alanyainknak, ha választaniuk kellene, újra ezt a szakmát választanák. Elégedettek, ha pedagógusi tapasztalataikra gondolnak. Szakmai kiégésről így nem beszélhetünk. A pedagógiai hivatás nehézségeivel azonban jól láthatóan tisztában vannak. Azzal már kevesebben értenek egyet, hogy mások számára is ajánlanák ezt a hivatást. Azzal is csak visszafogottabban tudnak egyetérteni a megkérdezettek, hogy több előnye volna a pedagógusi létnek, mint amennyi hátránya van. A két utolsó állítással kapcsolatban azonban egyértelmủ az egyet nem értés: a pedagógus szakma társadalmi megbecsültsége és jó megélhetést biztosító voltával inkább nem értenek egyet a kárpátaljai pedagógusok. Egy 2015-ös pedagógus-hallgatókat vizsgáló kutatás még azt állapította meg, hogy a Kárpát-medencében ebben a régióban érzik leginkább megbecsültnek szakmájukat a pedagógusjelöltek (Ferenc 2015: 122), ami a gyakorló pedagógusok között 2017-ben már inkább nem volt igaz. Egy 2005-2006ban készült másik kutatásból (Molnár 2009: 143) az derült ki, hogy a pedagógusok nem érzik úgy, hogy munkájukat nagyon hátráltatná az alacsony fizetés (egy 1-4 terjedő skálán - ahol 1 nagymértékben nehezíti és 4 egyáltalán nem nehezíti - a tanári fizetés 2,2 és 2,8 átlagértékeket kapott egyházi és állami iskolákban dolgozó pedagógusok körében), e trend azonban bő tíz év alatt megfordult. Veszélyként jelenik meg, hogy a korábbi felmérés adataihoz képest, megélhetési szempontból 2015-17-ben már nem érezték magukat elégedettnek sem a pályára készülő hallgatók (Ferenc 2015), sem a gyakorló pedagógusok. Mindez arra figyelmeztet, hogy a pedagógus szakma anyagi és társadalmi megítélésének javítására is szükséges figyelmet fordítani Kárpátalján.

17. ábra. Mennyire érzi magát boldognak? $(\mathrm{N}=301)$

(1-10-es skálán kapott átlagok, ahol 1= egyáltalán nem boldog, 10 = teljes mértékben boldog)

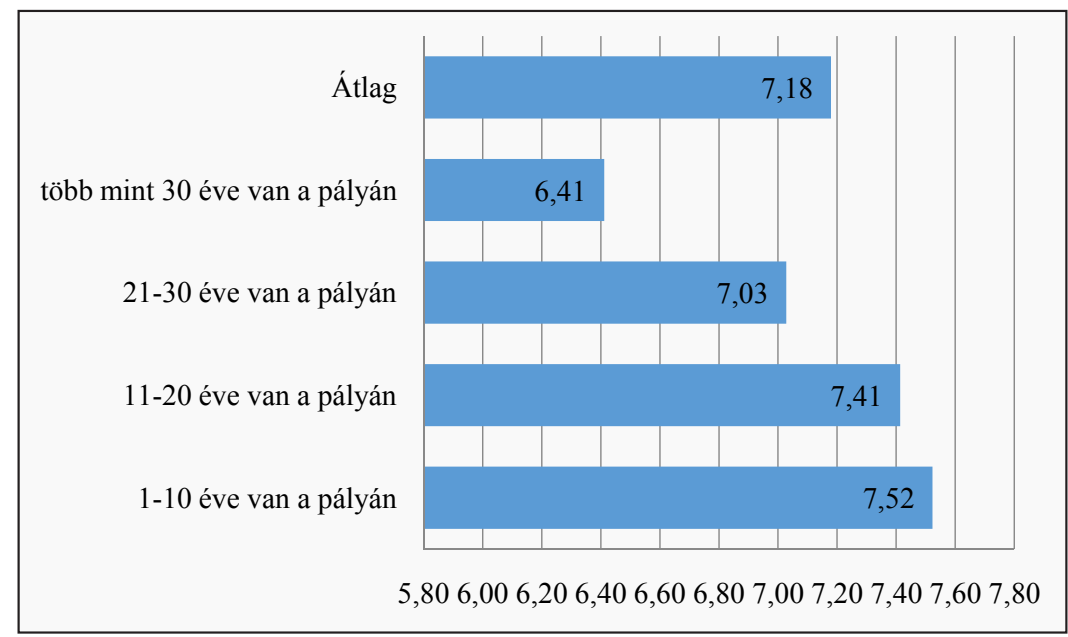

Forrás: Saját szerkesztés 


\section{TEMATIKUS TANULMÁNYOK - Kárpátalja társadalma}

Bár banális kérdés, de sok esetben árulkodó lehet az egyes társadalmi csoportok boldogság-indexe. Ezért a kárpátaljai magyar pedagógusokat is megkértük rá, hogy egy tízfokú skálán jelöljék, mennyire érzik magukat boldognak.

A tízfokú skálán az mutatható ki, hogy a pedagógusok átlagosan 7,2-es szinten, az inkább boldog kategóriába sorolják magukat. Mindössze 60 fö, azaz körülbelül a válaszadók 20\%-a sorolta magát az 5-ös felezőérték alatti (inkább boldogtalan) tartományba. A nemmel és a korcsoporttal nem, de a pályán eltöltött évekkel szignifikáns összefüggést mutat, hogy mennyire érzik magukat egy 10-es skálán boldognak a pedagógusok. Itt az a megállapítás tehető, hogy minél több időt töltött el a pedagógus a pályán, annál alacsonyabb a boldogság-érzete, ami minden bizonnyal nem csak ezzel van összefüggésben. A pedagógusok boldogság-indexe nem befolyásolja szignifikánsan a kitelepedési szándékokat, bár a migráción gondolkodók boldogtalanabbnak tűnnek $(6,68)$, mint azok, akik még nem gondolkodtak ezen az opción $(7,15)$, illetve azok a legboldogabbak $(7,65)$, akik elutasítják a kiköltözés gondolatát.

18. ábra. Boldogság-index a kitelepedési szándék szerint ( $\mathrm{N}=290)$.

(1-10-es skálán kapott átlagok, ahol 1 = egyáltalán nem boldog, 10 = teljes mértékben boldog) (fó, $\mathrm{N}=290$ )

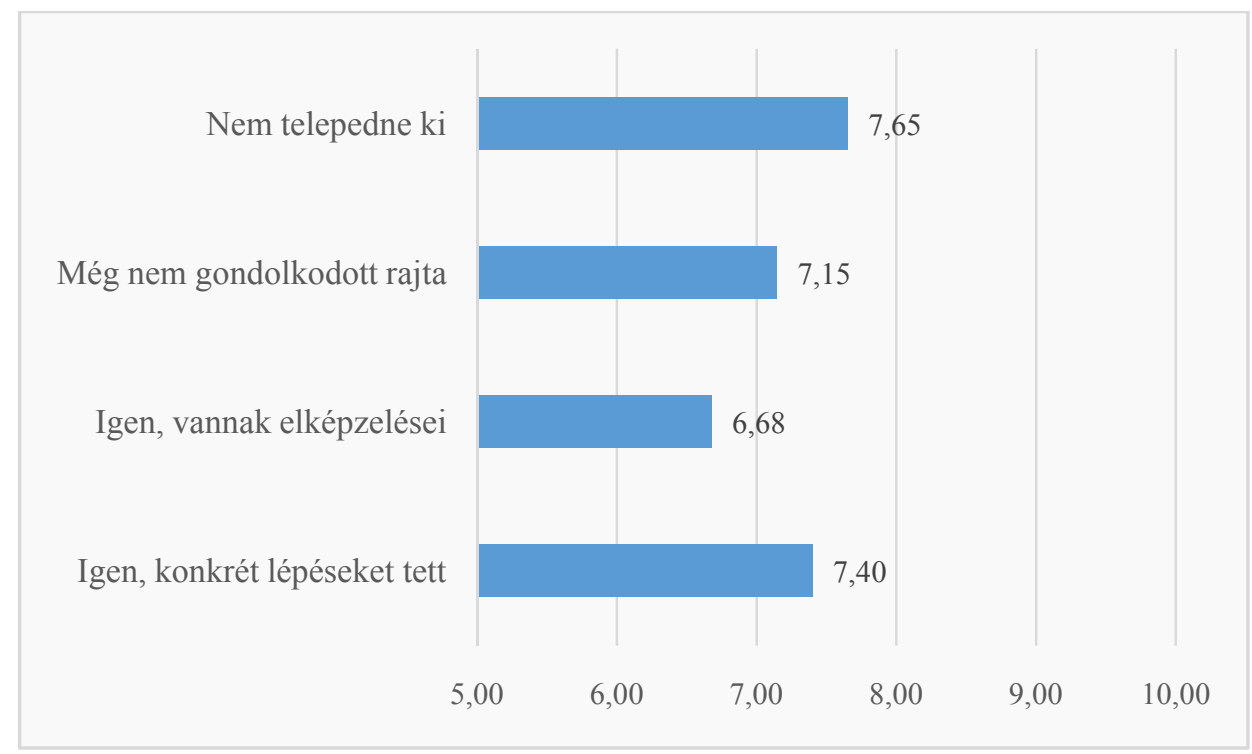

Forrás: Saját szerkesztés 


\section{TEMATIKUS TANULMÁNYOK - Kárpátalja társadalma}

\section{A migráció segítő tényezői: korábbi utazások, nyelvtudás és egy európai uniós útlevél}

A pedagógusok elvágyódási/elvándorlási szándékát abból a szempontból is vizsgáltuk, hogy mennyire mobilis ez a réteg: vagyis az elmúlt egy évben milyen gyakorisággal hagyták el az országot hosszabb-rövidebb időre. A 330 válaszadó között csupán 7\%-nyi azok aránya, akik az elmúlt egy évben nem utaztak külföldre. További 11\%ra az jellemző, hogy nem utazik minden évben, csupán néhány évenként. Ugyanakkor a megkérdezettek több mint fele (62\%) évente több alkalommal utazik külföldre. Ennél gyakrabban: vagyis havonta többször, hetente egyszer vagy többször a megkérdezettek egyötöde utazik külföldre.

19. ábra. Az elmúlt egy évben milyen gyakran lépte át az országhatárt? (\%; N=330)

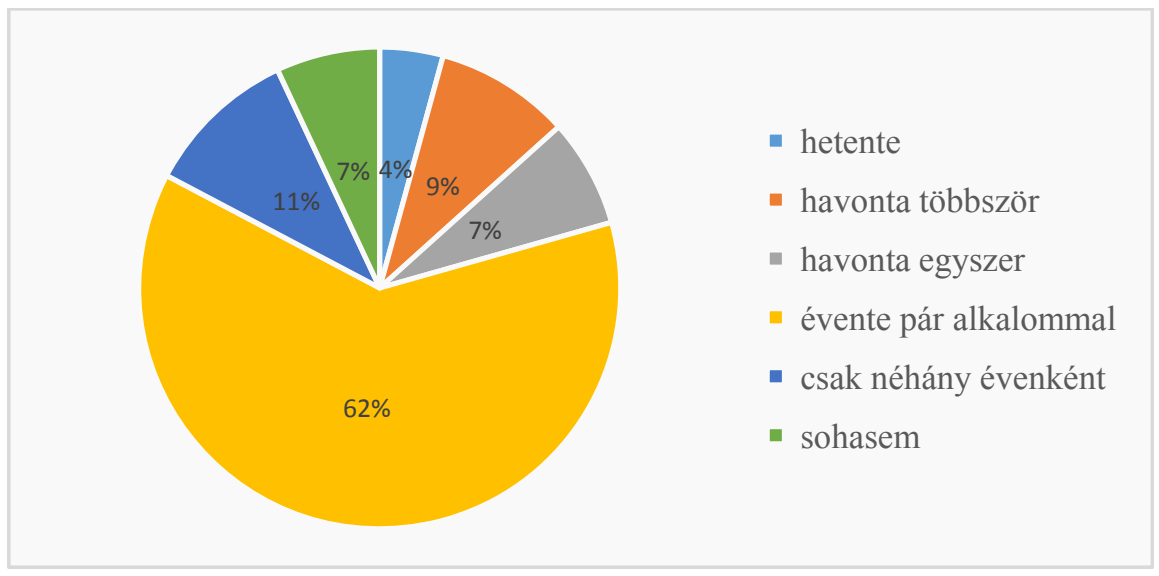

Forrás: Saját szerkesztés

A pedagógusok nagy része tehát rendelkezik saját gyakorlati mobilitási tapasztalatokkal, van reális elképzelése más országok megélhetési színvonaláról, feltehetően vannak baráti, családi hálózataik Ukrajna határain túl is. Az ilyen kapcsolatok, előőrsök megléte felerősítheti a migrációs tendenciákat. A pedagógusok között is azt találtuk, hogy a külföldi utazások gyakoriságának van hatása a kitelepedési szándékra (Khí-négyzet próba: 0,001). Az alábbi táblázatból azt láthatjuk, hogy azok nagy része (91\%), akik sohasem utaznak, még nem gondolkodtak a kitelepedésen, vagy kategorikusan elutasítják azt. A csak néhány évente utazók között is $84 \%$ azok aránya, akik inkább nem telepednének ki. Érdekes módon az állítás fordítva nem igaz: a gyakran utazók nem feltétlenül a leginkább elvándorlók, hiszen nem a leggyakrabban utazók közül kerül ki az a néhány fö, aki már konkrét lépéseket tett a kivándorlásra vonatkozóan. A gyakori utazók inkább a gondolkodók táborát erősítik (45\%), de majdnem 
www. metszetek.unideb.hu

\section{TEMATIKUS TANULMÁNYOK - Kárpátalja társadalma}

ekkora arányban vannak közöttük, akik még nem gondolkodtak a kitelepedésen (41\%), és 14\% azok aránya, akik elutasítják a kitelepedést.

6. táblázat. A külföldi utazások gyakoriságának hatása a kitelepedési szándékra (\%; N=318)

\begin{tabular}{|l|c|c|c|c|}
\hline $\begin{array}{l}\text { Utazások az elmúlt } \\
\text { egy évben/kivándorlás }\end{array}$ & $\begin{array}{c}\text { Igen, konkrét } \\
\text { lépéseket tett }\end{array}$ & $\begin{array}{c}\text { Igen, vannak } \\
\text { elképzelései }\end{array}$ & $\begin{array}{c}\text { Még nem gon- } \\
\text { dolkodott rajta }\end{array}$ & $\begin{array}{c}\text { Nem } \\
\text { telepedne ki }\end{array}$ \\
\hline $\begin{array}{l}\text { Heti, havi } \\
\text { rendszerességgel }\end{array}$ & $0,0 \%$ & $45,3 \%$ & $40,6 \%$ & $14,1 \%$ \\
\hline Évente pár alkalommal & $2,0 \%$ & $24,6 \%$ & $39,7 \%$ & $33,7 \%$ \\
\hline Csak néhány évenként & $0,0 \%$ & $15,2 \%$ & $33,3 \%$ & $51,5 \%$ \\
\hline Sohasem & $4,5 \%$ & $4,5 \%$ & $50,0 \%$ & $40,9 \%$ \\
\hline
\end{tabular}

Forrás: Saját szerkesztés

A migrációt elősegítő vagy hátráltató faktorok között a nyelvtudást is vizsgálni szokták, általában a célországban való boldoguláshoz szükséges nyelvismeret tekintetében. Esetünkben, mivel kisebbségi helyzetben élő adatközlőkről van szó két szempontból is érdekes a nyelvtudás kérdése: egyrészt a maradáshoz szükséges megfelelő nyelvtudási szintet is vizsgálnunk kell (ukrán nyelvtudás), másrészt a Magyarországon túlmutató migrációt erősítheti, ha az adatközlők a magyaron kívül még valamilyen nyugati idegen nyelvet, vagy a célország államnyelvét is beszélik.

Az alábbi nyelvtudásra vonatkozó diagramon kapott átlagokat egy hatfokú skálán kell értelmeznünk, ahol az 1-es fokozat a „nem érti és nem beszéli” kategóriájú nyelvtudást jelenti, a 6-os pedig az anyanyelvi szintet. Nem meglepő, hogy azt láthatjuk, a magyar nyelv esetében anyanyelvi nyelvtudásról számoltak be az adatközlők. A maradáshoz szükséges államnyelvet, az ukránt, a pedagógusok átlagosan a 4-es szinthez közelítően, vagyis jól beszélik, kisebb hibákkal. Az orosz nyelv is viszonylag magas értékkel, de a skála eggyel lentebbi lépcsőjén, a 3-as értékhez közel jelenik meg, vagyis az oroszt ugyan még beszélik a pedagógusok, de már kifejezési nehézségekkel.

A nyugati idegen nyelvek ugyanakkor nagyon elmaradnak az előző átlagoktól. Az angol nyelvtudás átlagos szintje a 2-es értékhez közelít, ami azt jelenti, hogy angolul a kárpátaljai pedagógusok értenek, de nem beszélnek. A német nyelv ettől még jobban lemarad, inkább a már „nem érti, nem beszéli”, 1-es érték felé húz. Az egyéb nyelvek esetében kevés értékelhető választ kaptunk, itt főleg a franciát említették, valamint ketten a szlovák és a cseh nyelvet. Azt találtuk azonban, hogy a nyelvtudásnak egyik nyelv esetében sincs szignifikáns hatása a kivándorlásra. 
www. metszetek.unideb.hu

\section{TEMATIKUS TANULMÁNYOK - Kárpátalja társadalma}

20. ábra. A pedagógusok nyelvtudása önbevallás alapján

(1-6-os skálán kapott átlagok, ahol 1 = nem érti és nem beszéli, 6 = anyanyelve)

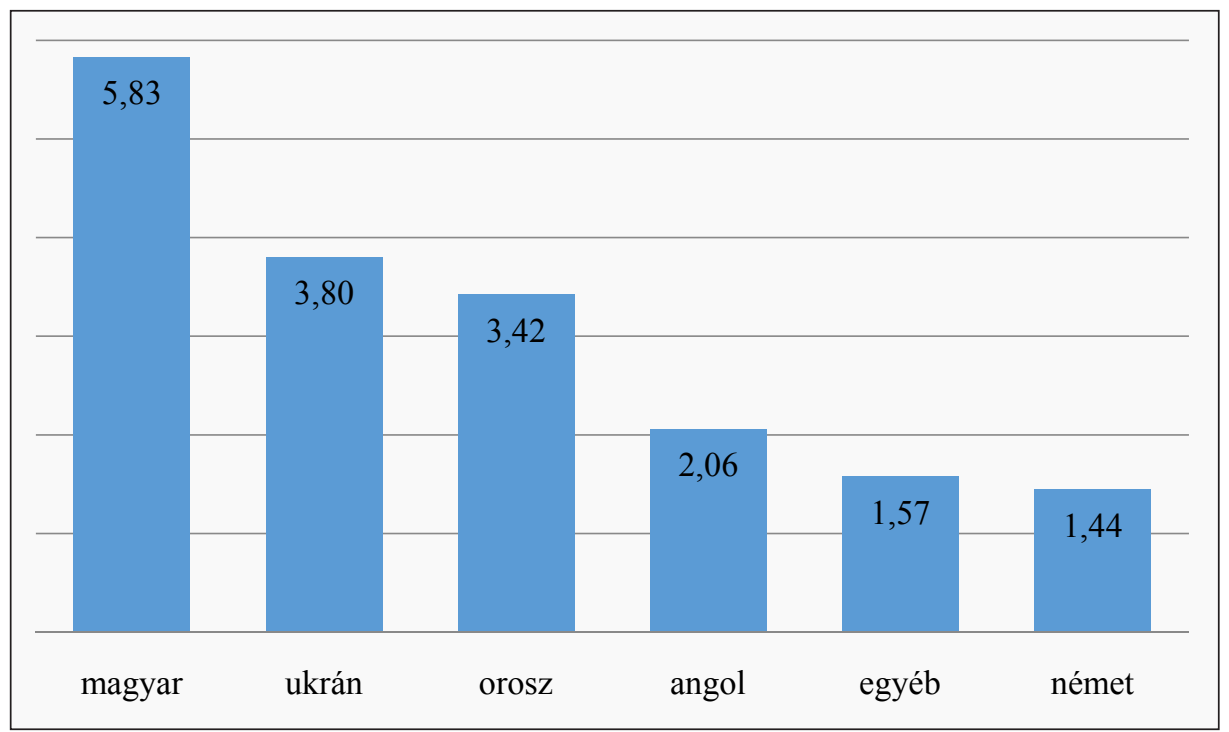

Forrás: Saját szerkesztés

Ha korcsoportok szerint is megvizsgáljuk a nyelvtudási szinteket, azt tapasztaljuk, hogy az orosz, az ukrán és az angol nyelv esetében szignifikáns különbségek vannak az életkori csoportok átlagai között. Az ukrán esetében enyhe emelkedés mutatható ki az életkor előrehaladtával: a 30 év alattiak 3,5-ös átlaga és az 50 felettiek 4,1-es átlaga közötti 0,6-es különbség ugyan egyazon nyelvi szinthez (4) tartozik, mégis fontos megjegyezni: hogy az idősebb generáció nem is tanulta az ukrán nyelvet formális oktatási keretek között, mégis jobban beszélik a nyelvet, mint a fiatalok. Az orosz nyelv esetében is ugyanez a generációs különbség figyelhető meg, csak sokkal nagyobb a két szélsőérték között különbség: ugyanis a fiatal generáció mintegy két egész szinttel rosszabbul beszéli az orosz nyelvet.

Az angol nyelvet ugyanolyan rosszul beszélik a fiatalabbak, mint az oroszt, de itt az látszik, hogy idősebb pedagógus kollégáikhoz képest egy akkora előny írható a javukra, mint amekkorát az államnyelv esetén a legidősebbek tudhattak magukénak velük szemben. 
www. metszetek.unideb.hu

\section{TEMATIKUS TANULMÁNYOK - Kárpátalja társadalma}

7. táblázat. Az adatközlők nyelvtudása korcsoportok szerint (átlagok)

\begin{tabular}{|l|c|c|c|c|c|c|}
\hline \multicolumn{1}{|c|}{ Korcsoportok } & magyar & ukrán & angol & német & orosz & egyéb \\
\hline 30 év alattiak & 5,9 & 3,5 & 2,2 & 1,4 & 2,1 & 1,0 \\
\hline 30-40 év közöttiek & 5,8 & 3,6 & 2,5 & 1,3 & 2,8 & 1,4 \\
\hline 40-50 év közöttiek & 5,9 & 4,0 & 1,8 & 1,4 & 4,1 & 1,5 \\
\hline 50 év felettiek & 5,8 & 4,1 & 1,6 & 1,7 & 4,3 & 2,2 \\
\hline Szignifikancia szint &, 834 & $\mathbf{, 0 0 1}$ & $\mathbf{, 0 0 1}$ &, 059 & $\mathbf{, 0 0 0}$ &, 026 \\
\hline
\end{tabular}

Forrás: Saját szerkesztés

Megállapítható, hogy a migrációt leginkább tervező fiatalabb generáció államnyelvtudása a legalacsonyabb, ezért a helyi integráció esetükben a leginkább korlátozott. Idegen nyelvtudásuk ugyan a legmagasabb a teljes vizsgált populációban, de alacsony ahhoz, hogy egy Magyarországon túli Nyugat-Európai országban boldoguljanak vele.

Az is megvizsgáltuk, hogy a pedagógusok közül mennyien rendelkeznek magyar állampolgársággal, s akik éltek az igénylés lehetőséggel, milyen motivációkból tették ezt, illetve hogyan köthető mindez össze a migrációs hajlandósággal. Természetesen, a kérdés érzékenysége miatt, többen éltek a nem válaszolás jogával, de még így is 270 adatközlő válaszai alapján tudjuk vizsgálódásainkat folytatni. A válaszadók nagy többsége (87\%) azt mondta, élt ezzel a lehetőséggel, további 10\% a jövőben kívánja a magyar állampolgárságot igényelni. Mindösszesen 3\% vallotta azt, hogy nem is áll szándékában a jövőben sem a magyar állampolgárságot igényelni.

Korcsoportok szerinti bontásban a legtöbb igénylő a 30-40 éves korosztályból került ki: összlétszámukhoz viszonyítva 78\% azok aránya, akik igennel válaszoltak a kérdésre. A 30 év alattiak 71\%-a, a 40-50 évesek 69\%-a, az 50 év felettiek 60\%-a válaszolt igennel.

Az állampolgárság igénylése mögött álló motivációkra is rákérdeztünk az igénylők körében. A négyfokú skálán kapott értékek értelmezésénél a skála felezőértékét, vagyis a 2,5-öt elérő tényezők valamilyen szinten fontosak voltak adatközlőink számára, míg a felezőérték alatti faktorok már a negatív, nem fontos, egyáltalán nem fontos mezőbe esnek. Láthatjuk, hogy az első helyen megjelenő, nagyon nagymértékben fontos tényező a pedagógusok állampolgárság igénylése mögött az érzelmi indíttatás, a felmenők magyarsága. Nagymértékben fontos tényező volt adatközlőink számára a gyermekeik jövőjének biztosítása az állampolgárság által. Ez lett a második helyezett a motivációk között. A harmadik helyen, szinte egyforma átlagértékkel végzett két tényező, amelyek a felezőérték alatt helyezkednek el, a kismértékben fontos kategóriánál: ezek a magyarországi egészségügyi szolgáltatások igénybevétele, valamint az olyan külföldi utazások megkönnyítése, amelyekhez egy magyarországi (európai uniós) útlevél jól szolgál. 
www. metszetek.unideb.hu

\section{TEMATIKUS TANULMÁNYOK - Kárpátalja társadalma}

21. ábra. A magyar állampolgárság megszerzésének motivációi (1-4-es skálán kapott átlagok, ahol 1= egyáltalán nem ért egyet, 4 = teljes mértékben)

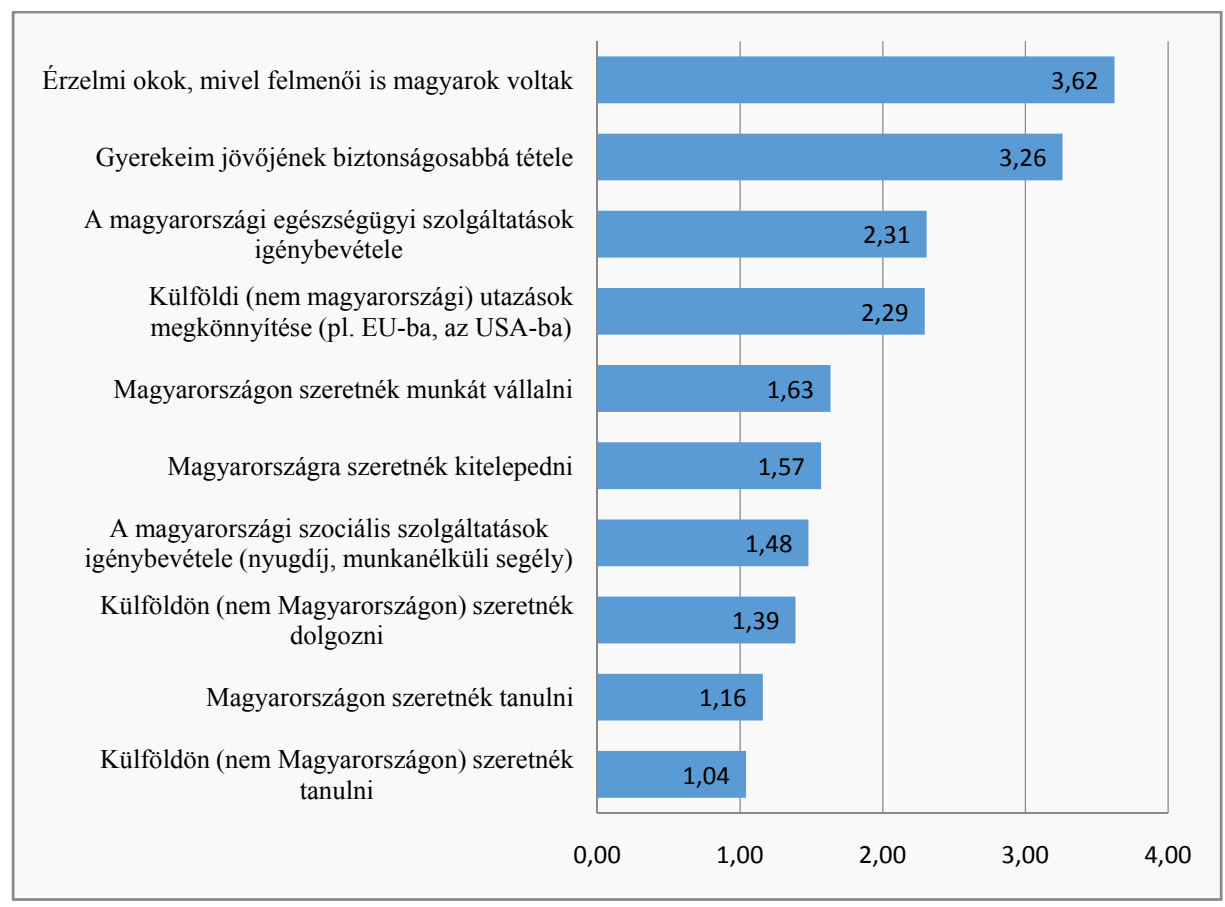

Forrás: Saját szerkesztés

A magyarországi munkavállalás, kitelepedés is csak kismértékben fontos a pedagógusok számára. A magyarországi szociális szolgáltatások igénybevétele, a külföldi (nem magyarországi) munkavállalás, és a magyarországi valamint külföldi tanulmányi célú migráció egyáltalán nem játszottak szerepet abban a döntésben, hogy a pedagógusok igényelték a magyar állampolgárságot.

Az állampolgársággal rendelkező és nem rendelkező pedagógusok kitelepedési szándékai szignifikánsan különböznek (Khí-négyzet próba: 0,002). 
www. metszetek.unideb.hu

\section{TEMATIKUS TANULMÁNYOK - Kárpátalja társadalma}

8. táblázat. Kitelepedési szándék a magyar állampolgársággal rendelkezés szerint

$(\% ; \mathrm{N}=265)$

\begin{tabular}{|l|c|c|c|c|}
\hline $\begin{array}{l}\text { Állampolgárság/ } \\
\text { kitelepedés }\end{array}$ & $\begin{array}{c}\text { Igen, konkrét } \\
\text { lépéseket tett }\end{array}$ & $\begin{array}{c}\text { Igen, vannak } \\
\text { elképzelései }\end{array}$ & $\begin{array}{c}\text { Még nem gondol- } \\
\text { kodott rajta }\end{array}$ & $\begin{array}{c}\text { Nem } \\
\text { telepedne ki }\end{array}$ \\
\hline $\begin{array}{l}\text { igényelte az állam- } \\
\text { polgárságot }\end{array}$ & $1,7 \%$ & $28,8 \%$ & $42,8 \%$ & $26,6 \%$ \\
\hline $\begin{array}{l}\text { nem igényelte, de } \\
\text { szándékában áll }\end{array}$ & $0,0 \%$ & $3,6 \%$ & $42,9 \%$ & $53,6 \%$ \\
\hline $\begin{array}{l}\text { nem igényelte, és nem } \\
\text { is áll szándékában }\end{array}$ & $0,0 \%$ & $0,0 \%$ & $25,0 \%$ & $75,0 \%$ \\
\hline
\end{tabular}

Forrás: Saját szerkesztés

Az állampolgársággal rendelkezők közül a legtöbben (43\%) nem gondolkodnak a kitelepedésen és körülbelül azonos arányban vannak a magyar állampolgársággal rendelkező pedagógusok között a kiköltözést kategorikusan elutasítók (27\%), mint a migrációs elképzelésekkel rendelkezők (29\%). A magyar állampolgársággal való rendelkezés így nem tekinthető a kiköltözés egyértelmű katalizátorának a megvizsgált pedagógusok körében: mindösszesen az állampolgárságot felvevők kicsivel több mint 30\%-a gondolkodik a kitelepedésen, és ebből 2\% konkrét lépéseket is tett. Az állampolgárságot a jövőben igényelni szándékozók és az igénylést elutasítók körében elenyésző a migrációs potenciál (az állampolgárságot a jövőben igényelni kívánók 3,6 \%-ának vannak elképzelései a kitelepedést illetően).

\section{Összegzés}

Kárpátaljai magyar gyakorló pedagógusok között végzett kérdőíves felmérésünket (N=338) e tanulmányban azzal a fó céllal elemeztük, hogy ismereteket nyerjünk a pedagógusok migrációs terveiről, valamint ezen tervek háttértényezőiről, mint a szakmai és anyagi elégedettség, a családi helyzet, a kor, a nyelvtudás, a magyar állampolgársággal való rendelkezés, vagy a tágabban értelmezett társadalmi-politikai közérzet.

Általánosságban a pedagógusok 32\% nem telepedne ki Kárpátaljáról. További 40\% pedig még nem gondolkodott rajta. Ez mindenképpen azt jelzi, hogy a kárpátaljai pedagógusok 72\%-a, bár elégedetlen helyzetével, de nem gondolkodik a kitelepedésen, vagy elutasítja annak gondolatát. A veszélyeztetettebb kategóriát az a 89 fő jelenti, akinek már vannak elképzelései a kitelepedéssel kapcsolatban (84 fő) vagy már konkrét lépéseket is tett (5 fő).

A migráció toló tényezői között, úgy gondoltuk, jelentős szerepe van a megélhetési gondoknak, a pedagógus szakma alacsony anyagi megbecsültségének, illetve 


\section{TEMATIKUS TANULMÁNYOK - Kárpátalja társadalma}

a krízis miatti gazdasági ellehetetlenülés tendenciájának. Ez a feltevésünk beigazolódott, hiszen a migrációt fontolgatók a legtöbben az anyagi elégedetlenség miatt hagynák el az országot: ezt az okot a mintából majdnem minden harmadik személy megjelölte. A válaszadók fele úgy véli, épp a határán van a megélhetésnek, 44\% pedig csak beosztással tud kijönni a havi bevételeiből. A gazdasági válság és a politikai krízis súlyos kombinációja rányomja a bélyegét a pedagógusok mindennapjaira: a kárpátaljaiak három legfontosabb problémája (1) a korrupció, (2) a kelet-ukrajnai háborús helyzet és (3) a pénztelenség és alacsony keresetek. Az oktatási rendszer problémái között első helyen jelennek meg a kisebbségellenes politikai döntések, de máris nyomában van az alacsony pedagógusbérek kérdése. A pedagógus szakma társadalmi megbecsültségével és jó megélhetést biztosító voltával inkább nem értenek egyet a kárpátaljai pedagógusok, ami negatív irányú változásra figyelmeztet a korábbi évek felméréseihez viszonyítva. Ugyanakkor szakmai kiégésről nem beszélhetünk.

Kutatásunk során azt feltételeztük, hogy inkább a fiatalabb korosztály számára vonzó a kitelepedés gondolata, illetve családi helyzet szempontjából az egyedülálló pedagógusok vannak jobban kitéve a migráció kisértésének. Szignifikáns eltérést találtunk a korcsoportok között a migrációra való hajlandóság tekintetében: bár a 40 év feletti, két legidősebb korcsoport között oszlik el az öt főre tehető „már konkrét lépéseket tett” elvándorlók köre, de a legfiatalabb, 30 év alatti korosztály teszi ki közel a felét (49\%) a migrációs elképzelésekkel rendelkezőknek.

Családi helyzet szempontjából a minta 80\%-a házas, 81\%-nak már gyereke is van. Úgy feltételeztük, hogy a stabil családi helyzet, a gyermekek megléte egyik oldalról mindenképpen a migráció ellen ható erő, hiszen családdal együtt mozogni sokkal nagyobb kockázatot jelent. Ez azonban nem igazolódott be egyértelműen. Nem találunk az egyedülállók és a családosok viszonylatában szignifikáns eltérést a kitelepedési terveket illetően, mint ahogyan a gyerekesek és a gyerekkel nem rendelkezők között sem. Ugyanakkor mintegy 5\%-al többen vannak a családos kategóriában a kitelepülni vágyók (28\%) az egyedülállókhoz képest, és 5\%-al több egyedülálló (77\%) mond inkább nemet a kitelepedésre, ${ }^{9}$ mint a családosok (72\%). Emellett picivel többen vannak a gyerekesek (73\%) a gyerekkel nem rendelkezőknél $(70 \%)$ a két kitelepedést ellenző kategóriában. Ugyanakkor a „nem telepedne ki" kategóriában többen vannak a gyerektelenek (39\% a 31\%-kal szemben). A fenti tendenciára részben magyarázattal szolgál, hogy a második legfontosabb migrációs motiváció (66 fő válasza alapján) a családi, párkapcsolati ok. Alanyaink 41\%-nak él külföldön családtagja (testvér és gyerek leginkább), közülük legtöbben (104 fő) Magyarországon.

\footnotetext{
${ }^{9}$ A „nem gondolkodott rajta” és „nem telepedne ki” kategóriák együtt.
} 


\section{TEMATIKUS TANULMÁNYOK - Kárpátalja társadalma}

Hipotézisként fogalmazzuk meg azt is, hogy a magyar állampolgársággal járó európai uniós útlevél megkönnyíti és előmozdítja a migrációt, valamint az alacsony ukrán nyelvtudás, illetve más nyugati idegen nyelvek magas szintű ismerete szintén a migrációt felerősítő faktorok.

Azt találtuk, hogy az állampolgársággal rendelkező és nem rendelkező pedagógusok kitelepedési szándékai szignifikánsan különböznek. A kivándorlásba kezdő 5 fő közül 4-nek van magyar állampolgársága. Az állampolgársággal rendelkezők közül ugyanakkor a legtöbben (43\%) nem gondolkodnak a kitelepedésen és körülbelül azonos arányban vannak a magyar állampolgársággal rendelkező pedagógusok között a kiköltözést kategorikusan elutasítók (27\%), mint a migrációs elképzelésekkel rendelkezők (29\%). A magyar állampolgársággal való rendelkezés így nem tekinthető a kiköltözés egyértelmű katalizátorának a megvizsgált pedagógusok körében: mindösszesen az állampolgárságot felvevők kicsivel több mint 30\%-a gondolkodik a kitelepedésen, és ebből 2\% konkrét lépéseket is tett. Az állampolgárságot a jövőben igényelni szándékozók és az igénylést elutasítók körében elenyésző a migrációs potenciál (az állampolgárságot a jövőben igényelni kívánók 3,6 \%-ának vannak elképzelései a kitelepedést illetően).

A nyelvtudásnak egyik nyelv esetében sincs szignifikáns hatása a kivándorlásra. Ugyanakkor megállapítható, hogy a migrációt leginkább tervező fiatalabb generáció államnyelvtudása a legalacsonyabb, ezért a helyi integráció esetükben a leginkább korlátozott. Idegen nyelvtudásuk ugyan a legmagasabb a teljes vizsgált populációban, de alacsony ahhoz, hogy egy Magyarországon túli nyugat-európai országban boldoguljanak vele.

\section{Irodalom}

Carrington, B. (2002): 'A quintessentially feminine domain? Student teachers' constructions of primary teaching as a career'. In: Educational Studies, 3: 287-303.

Caravatti, M. - McLeod Lederer S. - Lupico A. - Van Meter N. (2014): Study on teacher migration: Getting Teacher Migration \& Mobility Right. Education International. https://issuu.com/educationinternational/docs/teachermigrationstudy

Csernicskó, I. (2009a): Tények, adatok a kárpátaljai magyarok nyelvtudásáról. In: Együtt, 3: 70-77.

Csernicskó I. (2009b): Проблемні питання викладання української мови у школах з угорською мовою навчання. In: Герцог Ю. (ed): Державотворча й об’єднувальна функції української мови: реалії, здобутки, перспективи. Поліграф центр Ліра, Ужгород: 105-116.

Dokumentum. Ukrajna 2017. szeptember 5-én kelt 2145-VIII. sz. törvénye „Az oktatásról" (2017). In: Regio, 3: 260-277. 
www. metszetek.unideb.hu

\section{TEMATIKUS TANULMÁNYOK - Kárpátalja társadalma}

Ferenc, V. - Séra, M. (2012): Iskolaválasztás Kárpátalján. In: Kisebbségkutatás, 3: 473-513.

Ferenc V. (2013): Nyelvet tanulni, továbbtanulni, „létesülni” - többségi iskolaválasztási stratégiák Beregszászban. In: Kisebbségkutatás, 4: 98-121.

Ferenc V. (2014): Ami a nemzetközi mérésekben nem látszik: tanulói kompetenciák Kárpátalján. In: Kisebbségkutatás, 4: 188-221.

Ferenc V. (2015): Kik lesznek a jövő pedagógusai? - egyéni tényezők és intézményi hatás a kárpátaljai magyar nyelvű pedagógusképzésben. In: Kisebbségkutatás, 4: 89-123.

Grassi, Marzia - Tatiana Ferreira (eds.) (2016): Mobility and Family in Transnational Space. Cambridge Scholars Publishing, Newcastle upon Tyne

Korthagen, F. (2004): In search of the essence of a good teacher: towards a more holistic approach in teacher education. In: Teaching and Teacher Education, 77-97.

Menter, I. (2010): Teachers - formation training and identity: a literature review. Creativity, Culture and Education Series

Molnár, E. (2009): A kárpátaljai magyar pedagógustársadalom egy kérdőíves vizsgálat tükrében. In: Molnár, E. - Orosz, I. (szerk.): Oktatásügy határon. Kárpátaljai Magyar Kulturális Szövetség, Ungvár: 125-149.

Orosz, I. (2017): A kárpátaljai magyar nyelvű oktatás helyzetéről és minőségéről. In: Pusztai, G. - Márkus, Zs. (szerk.): Szülőföldön magyarul. Iskolák és diákok a határon túl. Debreceni Egyetem Kiadó, Debrecen: 42-71.

Papp, Z. A. (2013): Pedagógiai hozzáadott érték a roma tanulói arány függvényében a magyar iskolarendszerben. In: Bárdi, N. - Tóth, Á. (szerk.): Önazonosság és tagoltság. Argumentum, Budapest: 69-88.

Papp, Z. A. - Veres, V. (2007) (szerk.): Kárpát Panel 2007. A Kárpát-medencei magyarok társadalmi helyzete és perspektívái. MTA Kisebbségkutató Intézet, Budapest

Tátrai P. - Erőss Á. - Kovály K. (2016): Migráció és versengő nemzetpolitikák Kárpátalján az Euromajdan után. In: REGIO, 24, 3: 82-110. 